\title{
Sector models-A toolkit for teaching general relativity: II. Geodesics
}

\author{
C Zahn and U Kraus \\ Institut für Physik, Universität Hildesheim, Universitätsplatz 1, 31141 Hildesheim, \\ Germany \\ E-mail: corvin.zahn@uni-hildesheim.de, ute.kraus@uni-hildesheim.de
}

\begin{abstract}
.
Sector models are tools that make it possible to teach the basic principles of the general theory of relativity without going beyond elementary mathematics. This contribution shows how sector models can be used to determine geodesics. We outline a workshop for high school and undergraduate students that addresses gravitational light deflection by means of the construction of geodesics on sector models. Geodesics close to a black hole are used by way of example. The contribution also describes a simplified calculation of sector models that students can carry out on their own. The accuracy of the geodesics constructed on sector models is discussed in comparison with numerically computed solutions. The teaching materials presented in this paper are available online for teaching purposes at www.spacetimetravel.org.

Keywords: general relativity, geodesics, black hole, gravitational light deflection, sector models
\end{abstract}




\section{Introduction}

To teach the basic principles of the general theory of relativity without going beyond elementary mathematics remains a challenge even a century after the completion of the theory. In view of this objective, we describe a novel approach that is focussed on geometric insight and makes do with elementary mathematics as taught in school. This approach is suitable for learners who lack the qualifications or the time required to master the mathematical tools that are needed for a standard introductory text, i.e., advanced high school students and undergraduate students, especially those in a physics minor programme or in physics teacher education. The approach can also be used as a supplement to standard textbooks (e.g., Hartle 2003) to strengthen geometric insight.

In a first paper (Zahn and Kraus 2014, in the following referred to as paper I), we have developed sector models as a new type of physical model for curved spaces and spacetimes. We have shown how they can be used to convey the notion of a space or a spacetime being curved. In paper I, sector models were first introduced for twodimensional curved surfaces of positive or negative curvature. They were then developed for three-dimensional curved spaces and 1+1-dimensional curved spacetimes using the Schwarzschild black hole as an example.

Sector models implement the description of curved spacetimes used in the Regge calculus (Regge 1961) in the form of physical models. Figure 1 illustrates the basic principle using the surface of the earth by way of example: The surface is approximated by means of small flat elements of area. When these are laid out in the plane, one obtains a world map; this map is the sector model of the surface of the earth. Two differences to ordinary world maps stand out: The sector map is non-contiguous, since it is not possible to join all sectors simultaneously to all their neighbours. Also, the sector map is undistorted within the bounds of the discretization error, preserving both lengths and angles. It is, therefore, open to an intuitive geometric understanding. The sector model of a curved three-dimensional space is built along the same lines. The flat elements of area are replaced by blocks with euclidean geometry. In the case of a curved spacetime, the sectors are spacetime blocks with Minkowski geometry.

The general theory of relativity describes the paths of light and of free particles as geodesics of a curved spacetime. The notion of geodesics, therefore, is an important point in any introduction to general relativity. This contribution shows how sector models can be used to introduce the concept of geodesics and to determine geodesics by graphic construction. Instead of solving a system of ordinary differential equations, geodesics are constructed with pencil and ruler. The construction implements the description of geodesics in the Regge calculus (Williams and Ellis 1981) and gives quantitatively correct results (within the discretization error).

In this contribution, we outline a workshop on gravitational light deflection the way we teach it for high school and for undergraduate students (section 2). Section 3 is a discussion of the approximations involved in the construction of geodesics on sector models and a study of the accuracy that can be achieved. Conclusions and outlook 


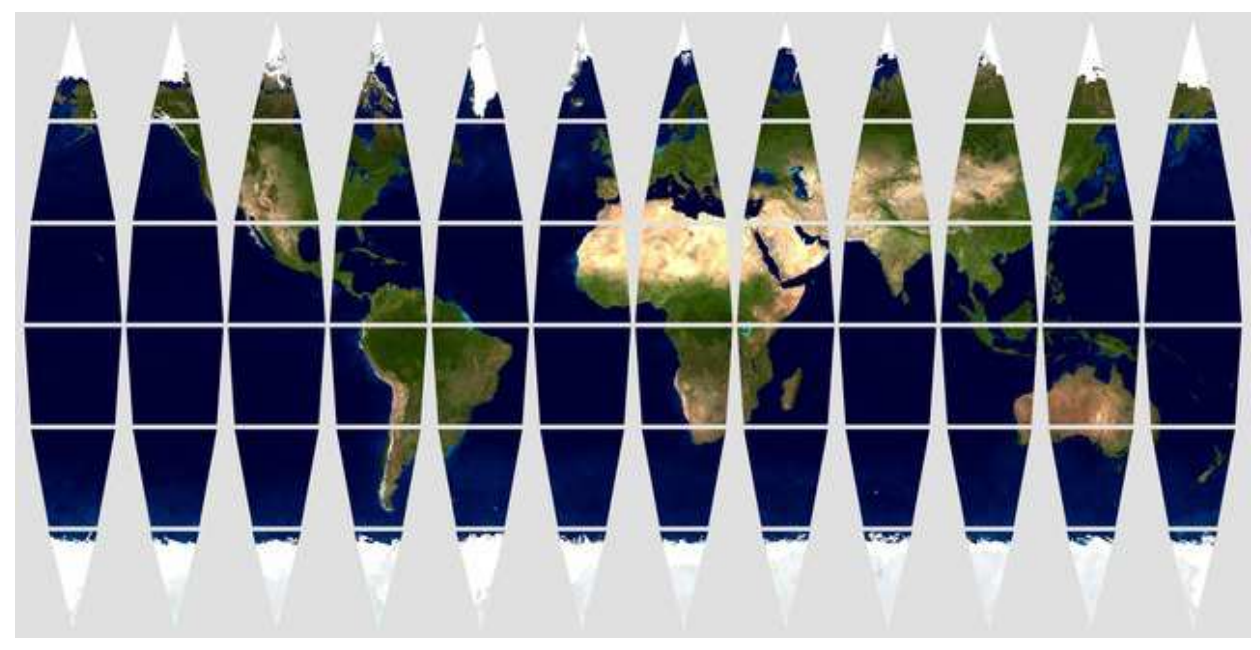

Figure 1. Sector model of the surface of the earth. Earth texture: NASA.

follow in section 4 .

\section{Workshop on geodesics and light deflection}

The workshop starts by introducing the concept of geodesics, using curved surfaces by way of example. Geodesics are then constructed on the sector model of a black hole in order to show how gravitational light deflection arises. The black hole is used as an example because close to it relativistic effects are large and, therefore, clearly visible in the graphic constructions. As an extension to the workshop, we describe a simplified procedure for the calculation of sector models that students can use to create sector models on their own. This enables them to study the geodesics of a spacetime starting from a given metric.

\subsection{Geodesics on curved surfaces}

The introduction to the workshop includes the explanation that the general theory of relativity describes the paths of light and of free particles as geodesics. Depending on the background of the participants, the significance of geodesics in general relativity may just be stated or may be explained in more detail with reference to the equivalence principle (e.g., Natário 2011, chapter 5). In preparation for the determination of geodesics in the vicinity of a black hole, geodesics are first studied on curved surfaces.

The geodesic line on a curved surface is introduced as a locally straight line. Such a line keeps its direction at each point, i.e., it neither bends nor kinks. A criterion is described that permits to recognize a geodesic: One imagines that a narrow strip made of a non-elastic material is glued along its centre line onto the line that is to be investigated. If the line bends, the strip tears on the outside and buckles on the inside - this shows that the line is not a geodesic.

The sphere is used as the first example (figure 21). We consider a line that starts 


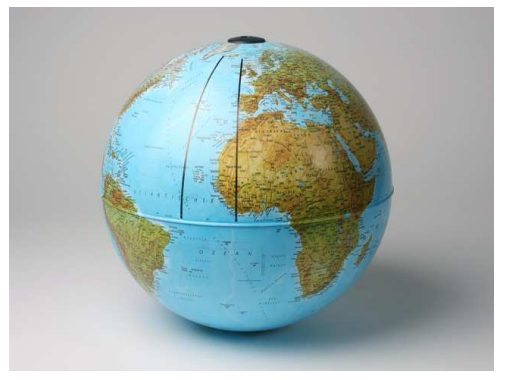

Figure 2. The geodesics on the sphere are the great circles.

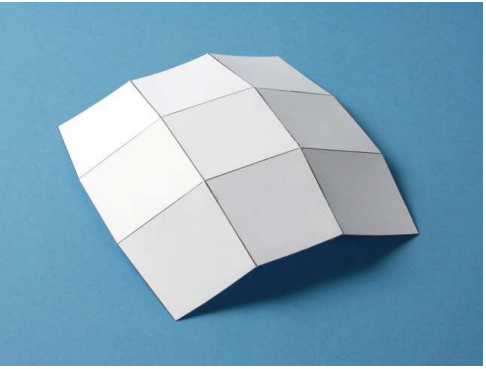

(a)

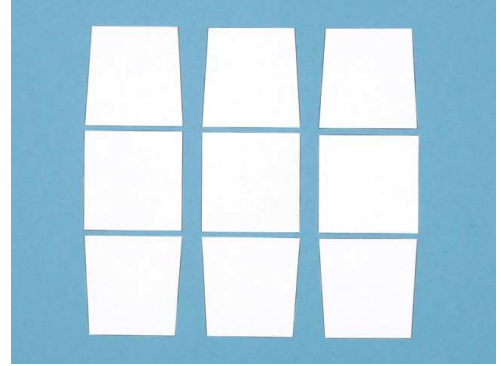

(b)

Figure 3. A spherical cap is approximated by facets (a) and represented as a sector model (b).

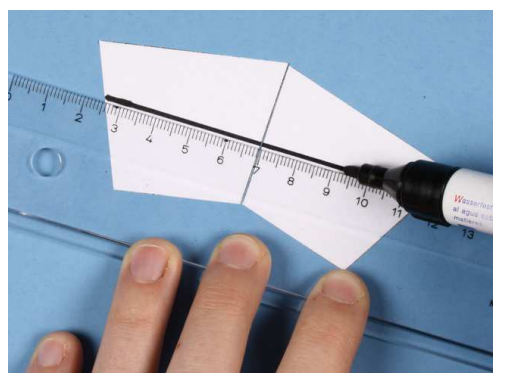

Figure 4. The construction of a geodesic on a sector model.

from the equator due north and is locally straight. It is obvious that the line is a line of longitude. The lines of longitude, and more generally all great circles, are geodesics on the sphere. Figure 2 illustrates a characteristic property of these geodesics: Two lines of longitude are parallel at the equator; towards the north pole they converge. Generally speaking, geodesics on the sphere converge when starting in parallel.

In the next step we show how this property of geodesics on the sphere can be obtained from a sector model. A spherical cap is approximated by facets (figure 3(a)), and the facets are laid out as a sector model (figure 3(b)). Now a geodesic is drawn onto the sector model. Within a sector, i.e., on a flat element of area, a geodesic is a straight line. When the line reaches the border of a sector, it is continued onto the neighbouring sector. How to do this follows from the definition of the geodesic: locally straight (figure 4). The two neighbouring sectors are joined at their common edge and 


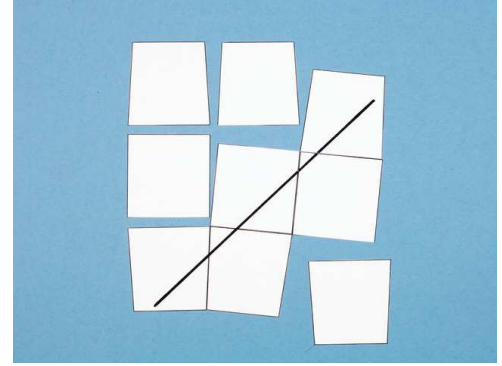

(a)

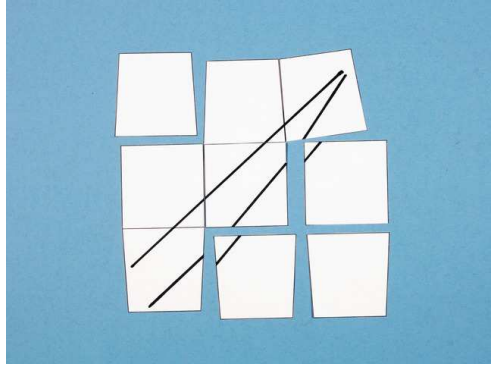

(b)

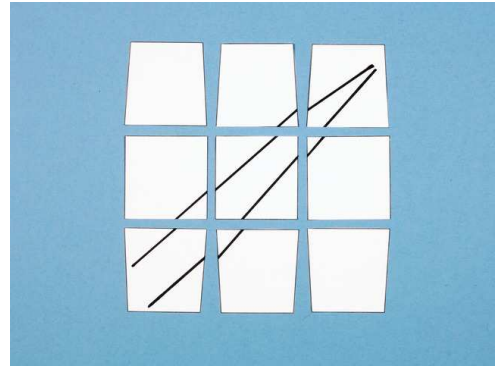

(c)

Figure 5. Geodesics on the sector model of a spherical cap. In (a) the sectors are joined along the bottom geodesic and in (b) along the top geodesic. The two geodesics are parallel in the bottom left sector and converge towards the right hand side ((b), (c)).

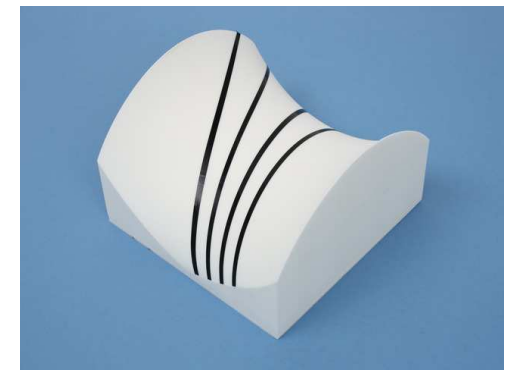

(a)

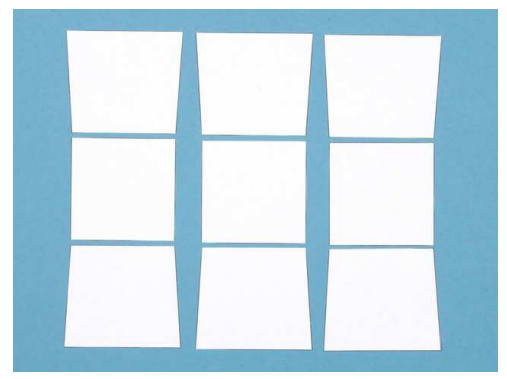

(c)

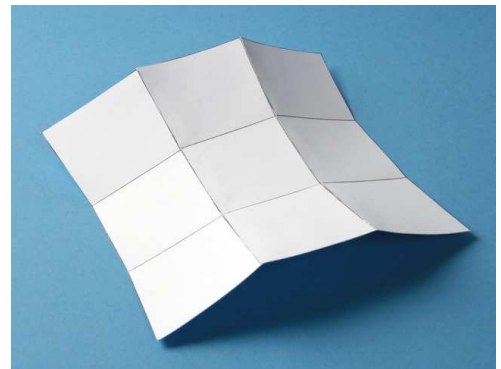

(b)

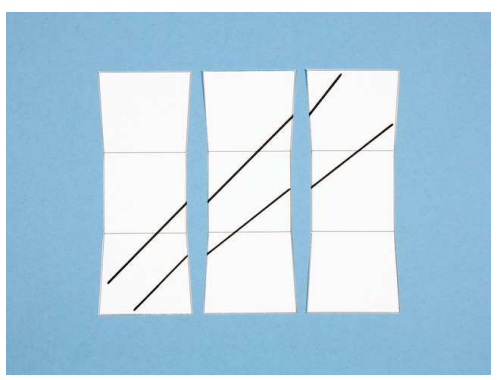

(d)

Figure 6. A saddle (a) is in part approximated by facets (b) and represented as a sector model (c); geodesics starting parallel to each other diverge $((a),(d))$.

the line is continued straight across the border. In this way the geodesic is continued across the sector model (figure 5(a)). A second geodesic is then added that is parallel to the first in the bottom left sector (figure 5(b)). One can see that the two geodesics starting in parallel on the lower left converge towards the right hand side (figures 5 (b), (c)).

A saddle is taken as a second example. Adhesive strips glued to the surface show that geodesics starting parallel to each other diverge (figure 6(a)). The approximation of a part of the surface by facets (figure 6(b)) leads to the sector model (figure 6(c)). 


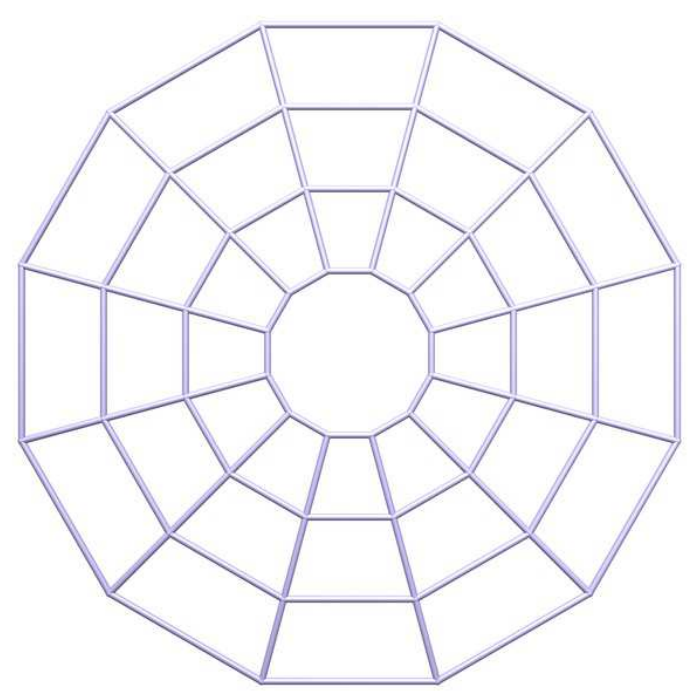

(a)

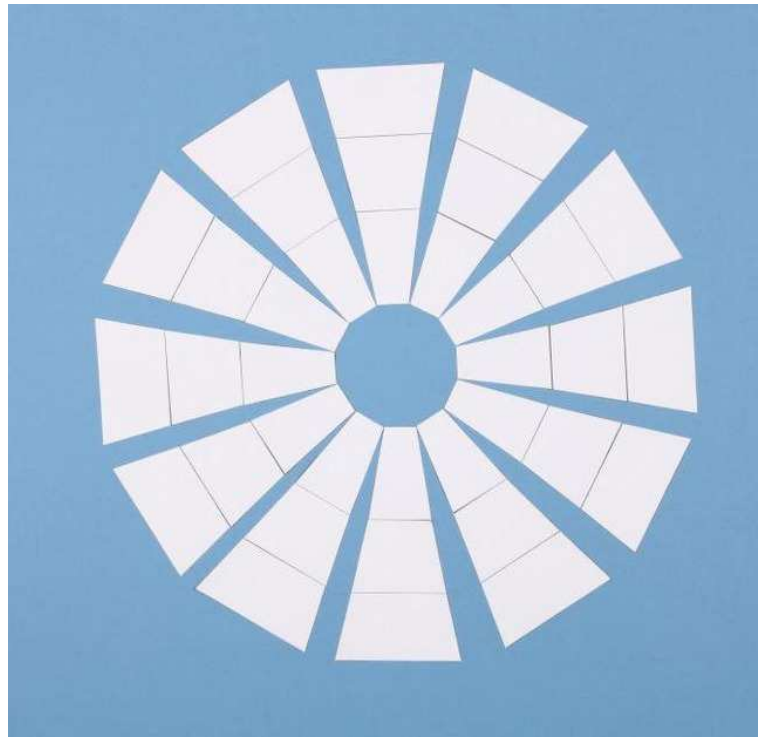

(b)

Figure 7. A thought experiment on the construction of the sector model of the black hole equatorial plane: A lattice is erected around the black hole according to the pattern shown in (a). For each cell, the lengths of the four enclosing rods are measured and from these data paper sectors are constructed true to scale. The result is the sector model of a ring around the black hole (b).

On the sector model, two geodesics are constructed that are parallel to each other in the lower left sector; these geodesics diverge (figure 6(d)).

The two examples show that sector models of curved surfaces can be used as tools to study the properties of geodesics on these surfaces.

\subsection{Geodesics close to a black hole}

The second part of the workshop begins with the presentation of a sector model that permits to construct geodesics in the vicinity of a black hole. The sector model represents a plane of symmetry of the black hole that in the following we will call equatorial plane $\$$

To introduce the sector model, its "construction" is described in a thought experiment: A spaceship is sent to a black hole with the task of surveying the space around it. To this end, a lattice is erected around the black hole according to the pattern shown in figure 7(a): Rigid rods are arranged like an orb web in the equatorial plane, centred on the black hole. The whole lattice is located outside of the event horizon because no such static structure is possible in the inner region of the black hole \$ Measurements are taken of the lattice: Each cell is enclosed by four rods. The lengths of the rods are measured and the data sent to Earth. There, each cell, reduced

$\ddagger$ We consider a non-rotating black hole. It has spherical symmetry, therefore, every geodesic lies in a plane that is a symmetry plane of the black hole.

$\S$ The lattice covers the region from 1.25 to 5 Schwarzschild radii in the Schwarzschild radial coordinate, see section 2.4.2 


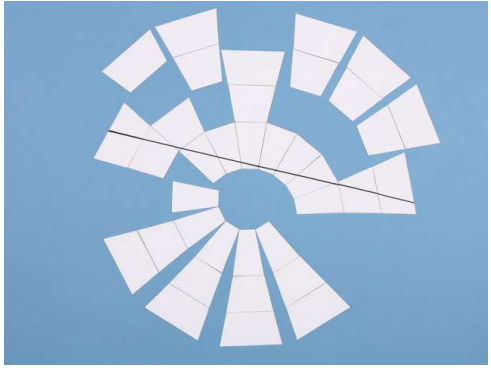

(a)

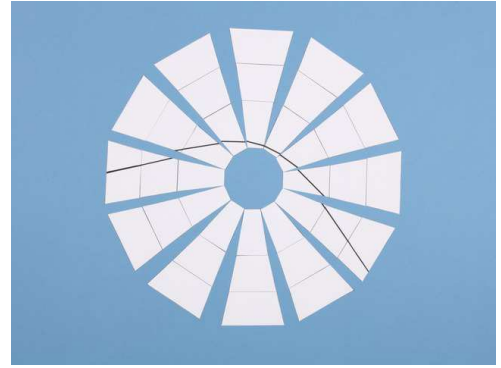

(b)

Figure 8. A geodesic on the sector model of the equatorial plane of a black hole. The line is locally straight; the direction "far behind" the black hole differs from the direction "far ahead". In (a) the sectors are joined along the geodesic and in (b) they are arranged symmetrically.

in size, is represented by a sector. The complete set of sectors forms a true to scale model of a ring around the black hole (figure Z(b)). Obviously, the sectors cannot be arranged to cover a ring without leaving gaps. This indicates that the geometry of the black hole equatorial plane is different from the geometry of the plane surface on which the sectors are laid out. The equatorial plane of the black hole is part of a curved space; the flat support of the model is a plane in euclidean space. If one could place a black hole with the appropriate mass in the centre of the model, then all the flat pieces with the sizes and shapes as shown would fit without gaps. The required mass amounts to about three earth masses for the cut-out sheet that is provided online (Zahn and Kraus 2018).

Alternatively, the sector model can be introduced via the workshop on curved space described in paper I. This workshop presents a sector model of the curved threedimensional space around a black hole (figure $5(\mathrm{~b})$ in paper I). The equatorial plane of this model (in figure 5(b) of paper I: the green, nearly horizontal sides of the blocks) is identical with the sector model shown in figure 7(b).

To build the sector model shown in figure 7(b), the sectors are cut out of a sheet of paper and are glued onto cardboard with spray adhesive (use repositionable spray adhesive for repeated lifting and repositioning)|W. The sector model is then used to study geodesics close to a black hole. First a single geodesic is drawn across the sector model. As in the case of the curved surfaces described above, this is done by joining neighbouring sectors and drawing a straight line (figure 8(a)). It can be seen that the two end sections of the line point in different directions (Fig $8(b))$. Thus, for a line that passes close to a black hole while keeping its direction at each point, the direction "far behind" the black hole differs from the direction "far ahead". This construction illustrates the principle underlying light deflection in a gravitational field: Light propagates on a locally straight path; when it passes a region of curved space, the direction of propagation afterwards is different from that before.

|| See section 2.3 for a method that does not require the use of adhesive. 


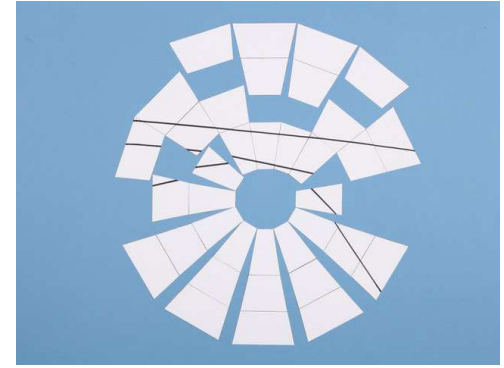

(a)

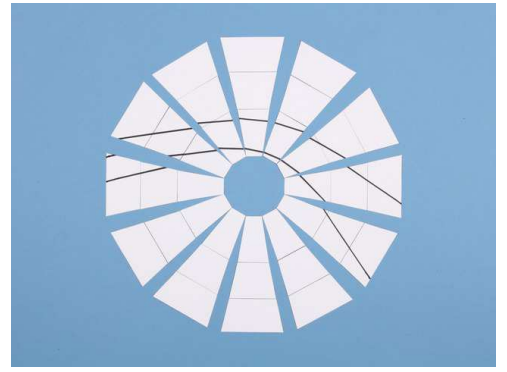

(b)

Figure 9. To the geodesic shown in figure 8 , a second geodesic is added that on the far left is parallel to the first: The inner geodesic is deflected more strongly, and the two geodesics diverge. In (a) the sectors are joined along the second geodesic, in (b) they are arranged symmetrically.

Two things must be borne in mind when assessing the significance of this construction on a sector model. First, the geodesics constructed on sector models are quantitatively correct. When the condition of a locally straight line is expressed

mathematically, the result is the geodesic equation (Weinberg 1972, p. $70 \mathrm{ff}$ ). The graphically constructed geodesic is a solution of this equation. Since the sector model is an approximate representation of the curved space, the geodesic drawn on it is likewise an approximate solution. Using an appropriately fine subdivision, geodesics can in principle be graphically constructed with high accuracy (section 3). Secondly one must bear in mind that though the line constructed above is a geodesic, it is not a light ray. This line is a geodesic in space. But light propagates in space and time, meaning that light rays are spacetime geodesics. Nevertheless, the geodesic in space illustrates by way of close analogy the principle behind gravitational light deflection.

Even though geodesics in space are not identical with light rays, it is instructive to use them for demonstrating properties of geodesics. One may for instance construct a second geodesic that starts close to the first and in the same direction (figure 9). The geodesic that runs closer to the black hole is deflected more strongly and the two geodesics diverge. Or one may construct two geodesics that come from the same point, pass the black hole on opposite sides, and meet again (figure 10). Thus, with geodesics it is possible to form a digon. Extrapolated to light rays, this construction shows how double images arise.

\subsection{The construction of geodesics using transfer sectors}

Figures 8, 9, and 10 show sectors that have been cut out of a sheet of paper and have been aligned along a geodesic or arranged symmetrically, as required. This procedure has the advantage that each geodesic can separately be displayed as a straight line. However, the construction of geodesics can be carried out more easily and more quickly without cutting out all the sectors. To this end, one uses the complete model in symmetric layout and with tick marks as shown in figure 11(a). A single additional column (figure 11(b)) 


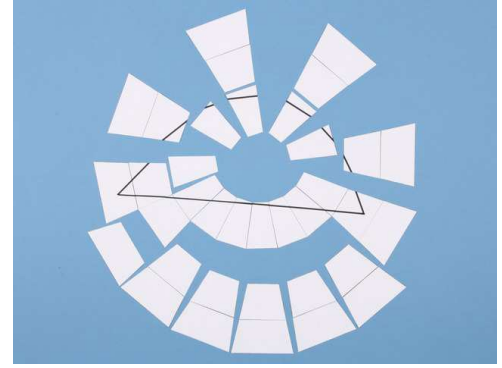

(a)

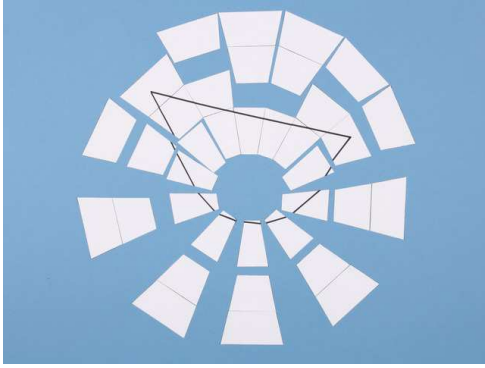

(b)

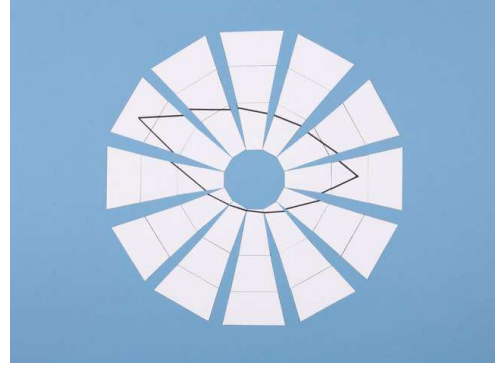

(c)

Figure 10. Two geodesics form a digon. This illustrates the formation of double images due to gravitational light deflection: Light emitted from a source reaches the observer along two different paths. In (a) and (b) the sectors are joined along the first and the second geodesic, respectively, in (c) they are arranged symmetrically.

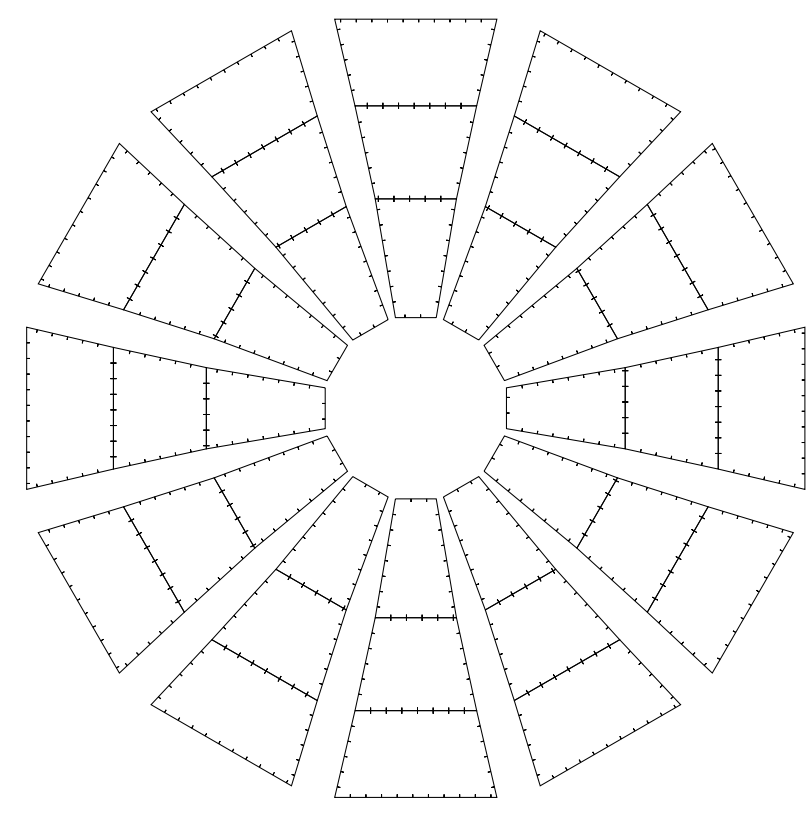

(a)

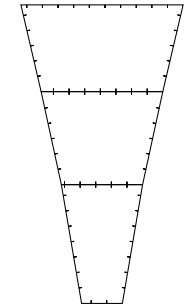

(b)

Figure 11. Worksheet for the construction of geodesics close to a black hole. The worksheet includes the sector model of the equatorial plane arranged symmetrically and with tick marks (a) and a column of transfer sectors (b). The length of the scale bar indicates the Schwarzschild radius $r_{\mathrm{S}}$ of the black hole.

is cut out of a sheet of paper, these are the so-called transfer sectors. The construction of a geodesic starts on the symmetric model and the line is first drawn up to the border of the column (figure 12(a)). The appropriate sector of the transfer column is then joined and the line is continued across the column of transfer sectors (figure 12(b)). The line on the transfer column is copied onto the neighbouring column of the symmetric model (figure 12(c)). This procedure is repeated up to the desired end point. In the model shown in figure 11(a), equidistant tick marks have been added at the borders to 


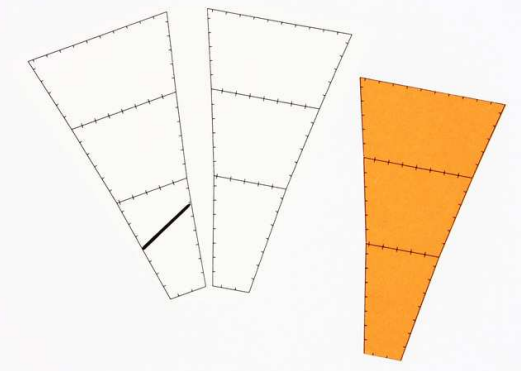

(a)

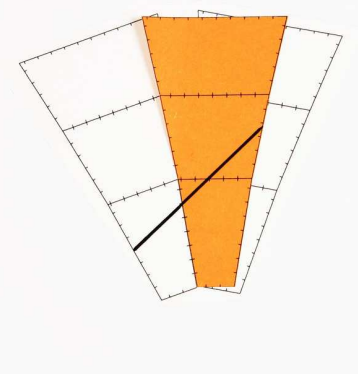

(b)

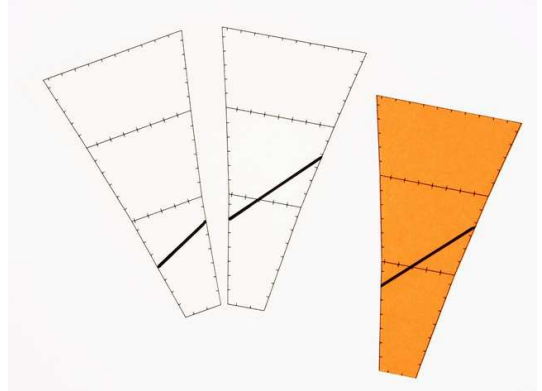

(c)

Figure 12. The construction of geodesics using transfer sectors (coloured). A geodesic is drawn up to the border of the column (a), continued across the transfer column (b), and copied from the transfer column onto the neighbouring column (c).

facilitate the copying of the lines. The worksheet shown in figure 11 is available online (Zahn and Kraus 2018).

\subsection{The construction of sector models}

A workshop can be implemented as described above, with sector models that are provided. This is the most elementary and the shortest type of workshop. But for sector models to realize their full potential as tools for studying curved spaces, the participants should calculate and construct the models on their own. This enables them to study other curved spaces in the same way, by, e.g., studying the geodesics corresponding to a given metric. Thus, setting up and solving the geodesic equation is replaced by creating the sector model and drawing the geodesics onto it.

The following section shows how one may introduce the calculation of sector models by using the sphere as an example. This procedure is then extended to the calculation of the sector model of the black hole equatorial plane.

2.4.1. Construction of the sector model of a spherical surface. This example serves to introduce the general procedure for the construction of sector models. The starting point is the concept of a metric as a function that takes the coordinates of two nearby points as arguments and returns their distance. This can be introduced in an elementary way by starting with curvilinear coordinates in the euclidean plane (e.g., Kraus and Zahn 2016; Hartle 2003, p. 21 f; Natário 2011, p. 35 f).

For the sector model of the sphere, the calculation is based on the metric in the usual spherical coordinates $\theta, \phi$ (figure 13(a)):

$$
\mathrm{d} s^{2}=R^{2} \mathrm{~d} \theta^{2}+R^{2} \sin ^{2} \theta \mathrm{d} \phi^{2},
$$

where $R$ is the radius of the sphere (for an elementary derivation that can be used in the workshop, see, e.g., Hartle 2003, p. 23 f; Natário 2011, p. 37 ff).

The creation of the sector model proceeds in three steps. In the first step the sphere is divided up into elements of area, defined by their vertices. In the example shown here, 


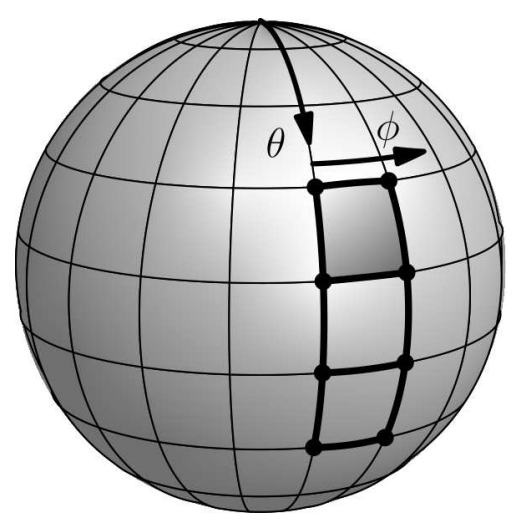

(a)

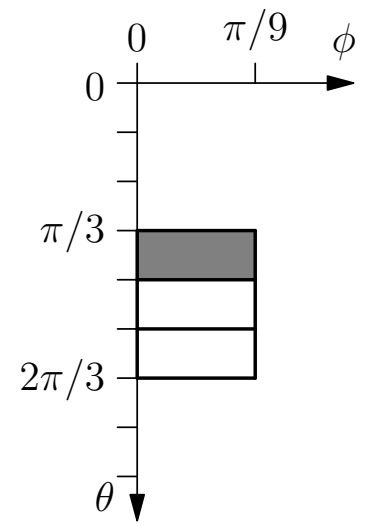

(b)

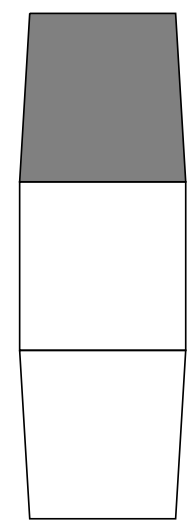

(c)

Figure 13. (a) The sphere described in polar coordinates $\theta, \phi$ and subdivided into elements of area of 20 degrees by 20 degrees. (b) Three elements of area in $\phi-\theta$ coordinate space. (c) The corresponding sectors. They make up one column of the model shown in figure 3(b). For clarity, one and the same sector is highlighted in grey in all three component images.

the elements of area are quadrilaterals with vertices at 20 degree $(\pi / 9)$ intervals in the angular coordinates $\theta$ and $\phi$, respectively (figures 13(a), (b)). In the second step the edge lengths of the quadrilaterals are computed. This is done in an approximate way in order to keep the calculation simple. For each edge, one determines the length by treating the end points as nearby points in the sense of the metric. For edges between vertices with the same longitude, one obtains the length

$$
\Delta s=R \Delta \theta \quad(\Delta \phi=0),
$$

in this example $\Delta s=R \pi / 9$. For edges between two vertices of the same latitude, one finds

$$
\Delta s=R \sin \theta \Delta \phi \quad(\Delta \theta=0),
$$

depending on the angle $\theta$ of the circle of latitude. For the sector models shown in the figures and provided online, the distance between vertices is determined along geodesics (see paper I). The difference between the approximate and the exact edge lengths amounts to $0.13 \%$ at most in this example.

In step three flat pieces of area are constructed from the edge lengths. In the present example, the elements of area on the sphere possess mirror symmetry. The flat pieces of area are constructed with the same symmetry property in the shape of symmetric trapezia (figure 13(c)).

2.4.2. Construction of the sector model of the equatorial plane of a black hole. The starting point of the calculation is the metric of the equatorial plane of a black hole

$$
\mathrm{d} s^{2}=\frac{1}{1-r_{\mathrm{S}} / r} \mathrm{~d} r^{2}+r^{2} \mathrm{~d} \phi^{2}
$$




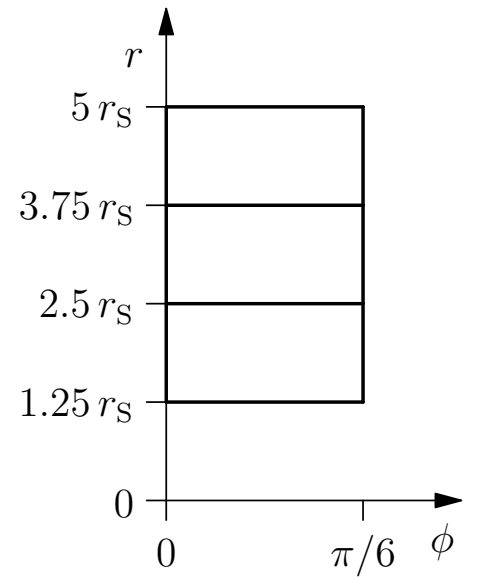

(a)

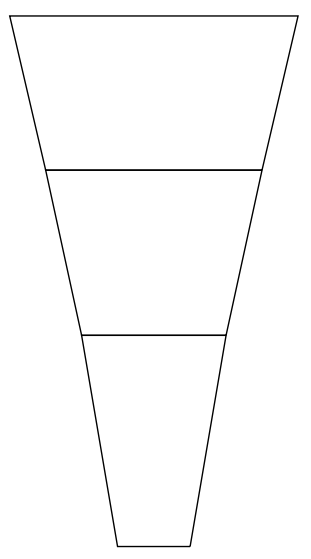

(b)

Figure 14. Construction of the sector model of the equatorial plane of a black hole. (a) The three elements of area of one column in $\phi-r$ coordinate space. (b) The corresponding sectors.

with the usual Schwarzschild coordinates $r$ and $\phi$. Here, $r_{\mathrm{S}}=2 G M / c^{2}$ is the Schwarzschild radius of the black hole with mass $M, G$ is the gravitational constant, and $c$ the speed of light. The sector model represents an annular part of the equatorial plane, centred on the black hole. The inner rim is located at $r=1.25 r_{\mathrm{S}}$ and the outer rim at $r=5 r_{\mathrm{S}}$. The azimuthal angle $\phi$ has values between zero and $2 \pi$.

First the ring is divided up into elements of area. For that purpose, the $\phi$-range is subdivided into twelve segments of coordinate length $\pi / 6$ each. Since the metric does not depend on the coordinate $\phi$, only one of the twelve segments needs to be calculated. The $r$-range is subdivided into three segments of coordinate length $1.25 r_{\mathrm{S}}$ each (figure 14(a)). Next, the edge lengths of the three quadrilaterals shown in figure 14(a) are calculated. Using the metric, the distance between vertices with the same value of $r$ is obtained as

$$
\Delta s=r \Delta \phi \quad(\Delta r=0) .
$$

When calculating the distance of vertices with the same $\phi$-coordinate, the first term of the metric comes into play. Its metric coefficient $1 /\left(1-r_{\mathrm{S}} / r\right)$ depends on $r$ and, therefore, varies along the edge. Here we make another approximation and use the metric coefficient at the mean $r$-coordinate $r_{\mathrm{m}}$ of the edge:

$$
\Delta s=\sqrt{\frac{1}{\left(1-r_{\mathrm{S}} / r_{\mathrm{m}}\right)}} \Delta r \quad(\Delta \phi=0),
$$

where $r_{\mathrm{m}}=\left(r_{1}+r_{2}\right) / 2$ with the coordinates $r_{1}$ and $r_{2}$ of the associated vertices. The sector models shown in the figures and provided online are constructed with edge lengths that are computed numerically for geodesics joining the vertices. The difference between the approximate and the exact edge lengths is largest for the innermost radial edge and there amounts to $5.4 \%$.

Step three is the construction of the quadrilaterals. The subdivision of the ring by radial cuts creates elements of area that possess mirror symmetry (figure 7(a)). 


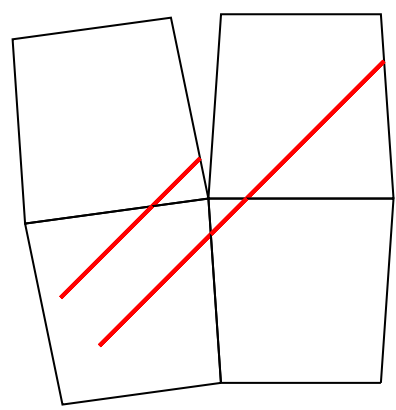

(a)

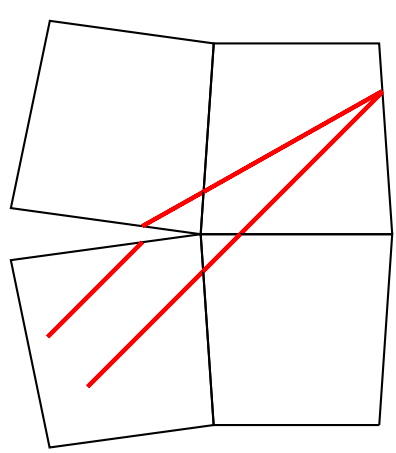

(b)

Figure 15. Two geodesics start in parallel (a), pass a vertex on opposite sides, and are then inclined towards each other by the deficit angle (b).

In accordance with this symmetry, the sectors are constructed as symmetric trapezia. Figure 14 shows the three sectors of a column together with the corresponding three rectangles in $\phi-r$ coordinate space. The complete sector model with twelve columns is shown in figure 11 .

\subsection{Geodesics vs. curvature}

When the workshop described above is combined with the workshop on curvature described in paper I (section 2), it is possible to address the connection between the curvature of a surface and its geodesics. In paper I, the sphere and the saddle are introduced as prototypes of surfaces with positive and negative curvature, respectively. The deficit angle at a vertex of the sector model is shown to be a criterion for curvature: Positive curvature is indicated by a positive deficit angle and vice versa

Using sector models, one can show that the paths of neighbouring geodesics also provide a criterion for determining curvature. Figure 15 shows neighbouring geodesics near a single vertex with positive deficit angle. Two geodesics that are parallel ahead of the vertex and pass the vertex on opposite sides (figure 15(a)) converge behind it (figure 15(b)). By construction, the angle between the two directions behind the vertex is the deficit angle.

Thus, geodesics starting in parallel indicate positive curvature if they converge. Conversely, they indicate negative curvature if they diverge. Two examples for this criterion are provided in section 2.1 in the form of geodesics on the sphere (figure 5 (c)) and on the saddle (figure 6(d)). Applied to the equatorial plane of a black hole where initially parallel geodesics diverge (figure 9), one concludes that the curvature is negative.

The argument given above is an illustration of the equation of geodesic deviation

$$
\left(\nabla_{\mathbf{u}} \nabla_{\mathbf{u}} \mathbf{D}\right)^{i}=-R_{j k l}^{i} u^{j} D^{k} u^{l}
$$

I The deficit angle of a vertex is positive if a gap remains after joining all adjacent sectors at this vertex (figure 15 gives an example). The deficit angle is negative if, after joining all the sectors except one, the remaining space is too small to accommodate the last sector. 
for two geodesics $x^{i}(\lambda)$ and $x^{i}(\lambda)+D^{i}(\lambda)$ with $u^{i}=d x^{i} / d \lambda$ and the Riemann curvature tensor $R_{j k l}^{i}$. In the sector model, the components of the Riemann curvature tensor are represented by the deficit angles (paper I, section 3) and figure 15 illustrates their impact on the change in distance between neighbouring geodesics.

\section{The accuracy of geodesics on sector models}

In the Regge calculus, geodesics are described as straight lines in the flat sectors (Williams and Ellis 1981, 1984, Brewin 1993). On the sector models, this description is implemented by graphic construction. Thus, the geodesics constructed in this way are in principle quantitatively correct. Their accuracy, however, depends on the resolution of the sector model. For use in the workshops, the resolution is deliberately chosen to be coarse, in order for the models to be easy to handle. In this section, we study the accuracy of the graphic method by comparing its results with numerically computed geodesics. Two sector models of the equatorial plane of a black hole are used in the comparison. Both cover the region between $r=1.25 r_{\mathrm{S}}$ and $r=13.75 r_{\mathrm{S}}$. The first one has the resolution used in the workshop $\left(\Delta r=1.25 r_{\mathrm{S}}, \Delta \phi=\pi / 6\right)$, it consists of 10 rings of 12 sectors each (figure 16(a)). The second one has four times this resolution in each coordinate $\left(\Delta r=0.3125 r_{\mathrm{S}}, \Delta \phi=\pi / 24\right)$, thus it consists of 40 rings of 48 sectors each (figure 16(b)). Figure 16 shows the geodesics obtained in the Regge calculus in comparison with the numerical solutions of the geodesic equation. For this comparison, the paths computed from the geodesic equation are plotted onto the sector models. The mapping of Schwarzschild coordinates onto sector points is carried out by interpolation (Hormann 2005). For a quantitative comparison, the angle of deflection as a function of the impact parameter was determined on the same two sector models and compared with the values obtained by integration (figure 17). On the sector models, ten geodesics were constructed for each value of the impact parameter. They are rotated in $\phi$ direction with respect to each other and thus have different locations with respect to the sector boundaries. For the coarser resolution, the agreement is good if the deflection is small, otherwise the deviation may be significant (figures 16(a), 17(a)). For the higher resolution sector model, the agreement is generally good (figures 16(b), 17(b)). For qualitative considerations, the accuracy on the sector model used in the workshop is satisfactory.

\section{Conclusions and outlook}

\subsection{Summary and pedagogical comments}

We have shown how sector models can be used as tools to determine geodesics. On the one hand this provides geometric insight and on the other hand it is a possibility

to determine geodesics graphically. The concept of a geodesic as a locally straight line is illustrated by implementing this definition directly on a sector model using pencil and ruler (section 2.1). The graphic construction of geodesics shows that their 


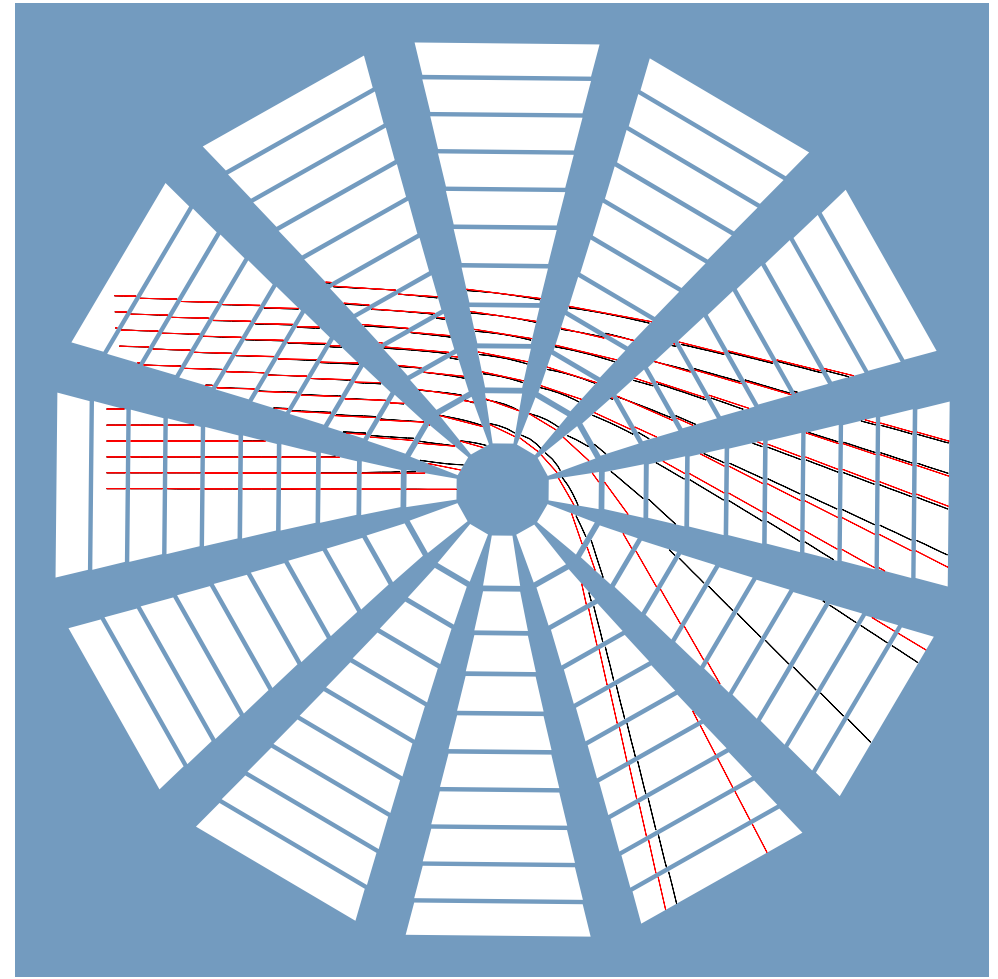

(a)

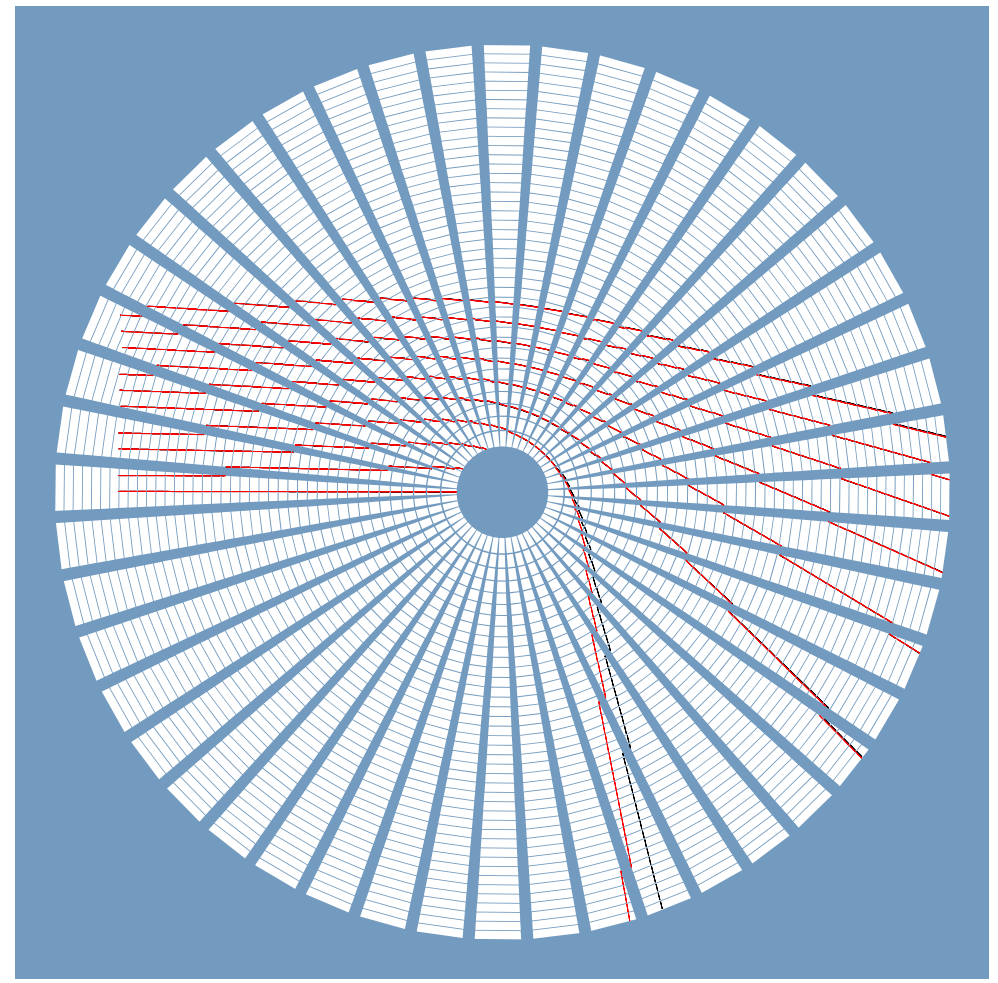

(b)

Figure 16. Geodesics constructed on sector models (red lines) in comparison with numerical solutions of the geodesic equation (black lines). (a) Sector model with the resolution used in the workshop. (b) Sector model with four times the resolution in each coordinate. 


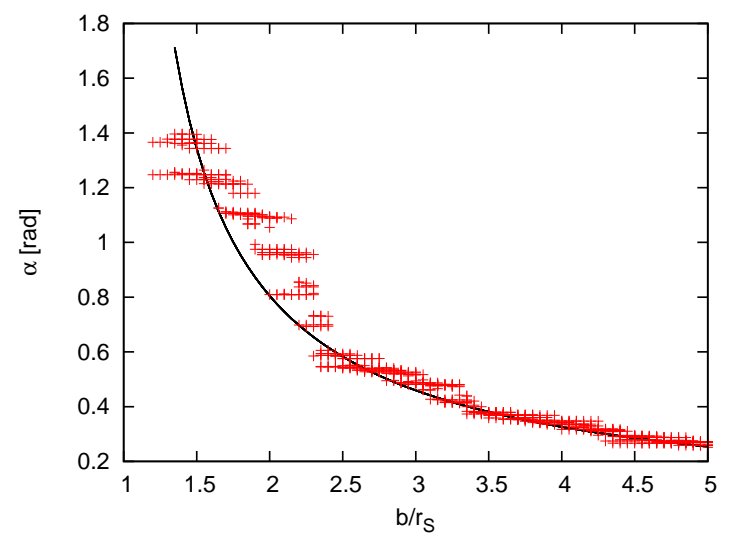

(a)

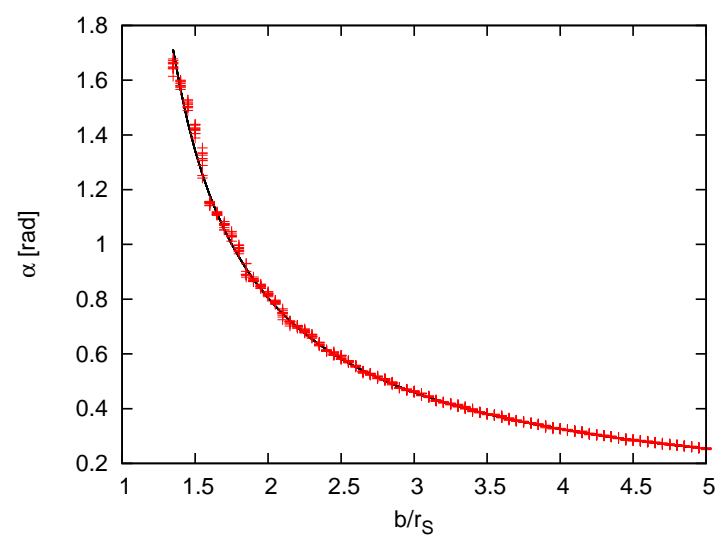

(b)

Figure 17. Relation between the angle of deflection $\alpha$ and the impact parameter $b$ of a geodesic, determined by constructing geodesics on a sector model (symbols) and by integrating the geodesic equation (line). (a) Sector model with the resolution used in the workshop. (b) Sector model with four times the resolution in each coordinate.

direction after crossing a region of curved space differs from the direction they had before (section 2.2), thus showing clearly how gravitational light deflection arises. Since the graphically constructed geodesics represent solutions of the geodesic equation, one obtains quantitatively correct results. Due to the rather coarse resolution of the sector models used in the workshop, the accuracy of these geodesics is not high. From a pedagogical point of view, though, a coarse resolution is an advantage. The deficit angles are then large enough to allow the illustration of the effects of curvature by considering a single vertex. This provides a clear picture of the connection between curvature and the run of neighbouring geodesics (section 2.5). In this paper we consider spatial geodesics only. An extension to geodesics in spacetime is described in the sequel to this contribution (Kraus and Zahn 2018).

The workshop on geodesics and gravitational light deflection outlined in this contribution has been developed in several cycles of testing and revision (Kraus and Zahn 2005, Zahn and Kraus 2010, 2013, Kraus and Zahn 2016). It was mainly tested with classes grades 10 to 13 (age 16 to 19 years) and with pre-service teachers.

There are different possible uses for the material presented above, depending on the teaching goals and on the time available. If the goal is to provide a short and direct approach to the phenomenon of gravitational light deflection, e.g. in an astronomy class, then the workshop can be held as described in sections 2.1 to 2.3 with the sector models provided as worksheets. No previous knowledge of the concept of metric is required; the graphic construction is easily carried out and conveys an appropriate understanding of light paths as geodesics. In a course that aims at introducing the basic concepts of general relativity, one can let the participants compute the sector models of the sphere and of the black hole equatorial plane. The participants then acquire the necessary 
skills for studying the geometry of a surface when they are given the metric. Answers are here obtained graphically that in a standard university course would be found by calculations. Since sector models and the graphic construction of geodesics directly correspond to the mathematical description by means of the metric and the geodesic equation, this material can also be used as a supplement to a standard course in order to strengthen geometric insight.

\subsection{Comparison with other graphic approaches}

In comparison with other graphic representations of geodesics, constructions on sector models stand out by the fact that they clearly show geodesics to be locally straight as well as by their straightforward construction.

Explanations of optical phenomena due to gravitational light deflection, e.g. double images, typically use drawings that depict light rays as curved lines. In this context, light rays are described as "bent". These drawings and explanations do not express the fact that light paths are geodesics, i.e. (locally) straight lines, and may thereby encourage misconceptions. The construction of geodesics on sector models clearly shows that there is no contradiction between the line being locally straight and the occurrence of light deflection (figure 8). The construction can also relate geodesics to light rays being drawn as curved lines: On a world map, the surface of the earth is projected onto the plane and the geodesics of the sphere appear as curved lines. These are distortions due to the projection. Analogously, in a projection that maps the sector model of figure 8 onto a plane circular ring, there will be distortions and the geodesics in the equatorial plane of the black hole will appear curved.

A commonly used visualization shows geodesics on the embedding surface of the equatorial plane of a star or a black hole in order to illustrate the deflection of light (d'Inverno 1992, p. 209). This is equivalent to the geodesics constructed in section 2.2. When the sectors of the model shown there are joined at the common edges, one obtains a faceted surface that is an approximation of the embedding surface. The same caveat applies to the geodesics on the embedding surface as to the geodesics on the sector model: The subspace is purely spatial so that gravitational light deflection is illustrated by way of analogy with spacelike geodesics. Experience shows that the concept of an embedding surface is a difficult one for the audience at which this workshop is targeted and that the embedding surface is quite likely to be misinterpreted as the geometric shape of the black hole (Zahn and Kraus 2010). With respect to embedding surfaces, sector models have the advantage that their calculation is elementary, especially with the simplified method of section 2.4. Also, sector models are easily built as physical paper models and are readily duplicated, so that all participants of a workshop can carry out the construction of geodesics on models of their own.

A description of geodesics that is related to the representation on sector models

is diSessa's construction on so-called wedge maps (diSessa 1981). To create a wedge map, the symmetry plane of a spherically symmetric spacetime is divided up into strips 
by a number of radial cuts; the strips (the wedges) are regarded as flat segments. On the wedges, geodesics are determined numerically as in the Regge calculus. Thus, the construction of geodesics on the wedge map follows the same prescription that is used here for sector models. The numerical method, however, is more involved than the graphic construction used here, concerning both the mathematical description and the requirement of programming skills.

\subsection{Outlook}

In paper I, three fundamental questions were raised that should be answered by an introduction to general relativity: What is a curved spacetime? How does matter move in a curved spacetime? How is the distribution of matter linked to the curvature of the spacetime? The concept of curved spaces and spacetimes was discussed in paper I. To address the second question, the present part II describes geodesics in space and its sequel describes geodesics in spacetime (Kraus and Zahn 2018). The relation between curvature and the distribution of matter will be treated in a fourth part of this series.

\section{References}

Brewin L 1993 Particle paths in a Schwarzschild spacetime via the Regge calculus Class. Quantum Grav. 10 1803-23

d'Inverno R 1992 Introducing Einstein's Relativity (Oxford: Clarendon Press)

diSessa A 1981 An elementary formalism for general relativity Am. J. Phys. 49 (5) $401-11$

Hartle J 2003 Gravity (San Francisco: Addison Wesley)

Hormann K 2005 Barycentric Coordinates for Arbitrary Polygons in the Plane, Technical Report No. 5, Institute of Computer Science, Clausthal University of Technology, Germany

Kraus U and Zahn C 2005 Wir basteln ein Schwarzes Loch - Unterrichtsmaterialien zur Allgemeinen Relativitätstheorie Praxis der Naturwissenschaften Physik, Didaktik der Relativitätstheorien 4/54 38-43

Kraus U and Zahn C 2016 Teaching gravitational light deflection: A short path from the metric to the geodesic www.spacetimetravel.org/aur16

English translation of: Lichtablenkung für die Schule: Von der Metrik zur Geodäte Astronomie und Raumfahrt im Unterricht 53 (3-4/2016) 43-9

Kraus U and Zahn C 2018 Sector models - A toolkit for teaching general relativity: III. Spacetime geodesics, submitted

Natário J 2011 General Relativity Without Calculus (Springer)

Regge T 1961 General relativity without coordinates Il Nuovo Cimento 19 558-71

Weinberg S 1972 Gravitation and Cosmology (Wiley) 
Williams R M and Ellis G F R 1981 Regge Calculus and Observations. I. Formalism and Applications to Radial Motion and Circular Orbits Gen. Rel. Grav. 13 (4) 361-95

Williams R M and Ellis G F R 1984 Regge Calculus and Observations. II. Further Applications Gen. Rel. Grav. 16 (11) 1003-21

Zahn C and Kraus U 2010 Workshops zur Allgemeinen Relativitätstheorie im Schülerlabor „Raumzeitwerkstatt“ an der Universität Hildesheim PhyDid B DD 09.03

Zahn C and Kraus U 2013 Bewegung im Gravitationsfeld in der Allgemeinen Relativitätstheorie - ein neuer Zugang auf Schulniveau PhyDid B DD 17.13

Zahn C and Kraus U 2014 Sector models - A toolkit for teaching general relativity: I. Curved spaces and spacetimes Eur. J. Phys. 35 (5) 055020

Online version with supplementary material: www.spacetimetravel.org/sectormodels1 (paper I)

Zahn C and Kraus U 2018 Online resources for this contribution

WWW.spacetimetravel.org/sectormodels2 


\title{
Sektormodelle - Ein Werkzeugkasten zur Vermittlung der Allgemeinen Relativitätstheorie: II. Geodäten
}

\author{
C Zahn und U Kraus \\ Institut für Physik, Universität Hildesheim, Universitätsplatz 1, 31141 Hildesheim \\ E-mail: corvin.zahn@uni-hildesheim.de, ute.kraus@uni-hildesheim.de
}

\section{Zusammenfassung.}

Sektormodelle sind Werkzeuge, mit denen die Grundprinzipien der Allgemeinen Relativitätstheorie vermittelt werden können, ohne bei der Formulierung über Schulmathematik hinauszugehen. Dieser Beitrag zeigt, wie Sektormodelle dazu verwendet werden können Geodäten zu bestimmen. Wir stellen einen Workshop für Schüler/innen und Studierende vor, in dem die gravitative Lichtablenkung mittels der Konstruktion von Geodäten auf Sektormodellen behandelt wird; als Beispiel dienen Geodäten in der Nähe eines Schwarzen Lochs. Der Beitrag beschreibt ferner eine vereinfachte Berechnung von Sektormodellen, die Schüler/innen und Studierende selbst durchführen können. Die Genauigkeit der auf Sektormodellen konstruierten Geodäten wird im Vergleich mit numerisch berechneten Lösungen diskutiert. Die vorgestellten Materialien stehen online unter www.tempolimit-lichtgeschwindigkeit.de für den Unterricht zur Verfügung. 


\section{Einleitung}

Die Allgemeine Relativitätstheorie ohne den mathematischen Apparat in ihren Grundzügen zu vermitteln ist ein Anliegen, das auch hundert Jahre nach der Entwicklung der Theorie nichts an Aktualität verloren hat. Im Hinblick auf dieses Ziel beschreiben wir einen neuen Zugang, der mit Schulmathematik auskommt. Zielgruppe sind Schüler/innen der Sekundarstufe sowie Bachelor-, Lehramts- und Nebenfachstudierende, d.h. Interessent/innen, denen entweder das Vorwissen oder die Zeit fehlen, um sich den für die übliche Darstellung benötigten mathematischen Apparat anzueignen. Dieser Zugang kann aber auch als Ergänzung zu Standardlehrbüchern (z. B. Hartle 2003) eingesetzt werden, um ein anschauliches, geometrisches Verständnis zu fördern.

In einer ersten Arbeit (Zahn und Kraus 2014, im Folgenden als Teil I bezeichnet) haben wir Sektormodelle als neuen Typ von Anschauungsmodellen für gekrümmte Räume und Raumzeiten entwickelt. Wir haben aufgezeigt, wie mit ihrer Hilfe eine Vorstellung von gekrümmten Räumen und Raumzeiten vermittelt werden kann. Sektormodelle werden in Teil I anhand von zweidimensionalen, positiv bzw. negativ gekrümmten Flächen eingeführt und dann am Beispiel des Schwarzen Lochs auf dreidimensionale gekrümmte Räume und 1+1-dimensionale gekrümmte Raumzeiten erweitert.

Sektormodelle realisieren die im Regge-Kalkül eingesetzte Darstellung gekrümmter Raumzeiten (Regge 1961) in Form von gegenständlichen Modellen. Abb. 1 illustriert das Prinzip am Beispiel der Erdoberfläche: Die Oberfläche der Erdkugel wird durch kleine, ebene Flächenstücke angenähert. Legt man die Flächenstücke in der Ebene aus, erhält man eine Weltkarte; diese stellt das Sektormodell der Erdoberfläche dar. Zwei Unterschiede zu üblichen Weltkarten fallen ins Auge: Die aus Sektoren bestehende Weltkarte hat kein geschlossenes Kartenbild, da sich die Sektoren nicht sämtlich lückenlos aneinanderfügen lassen. Und die Sektorkarte ist im Rahmen der Diskretisierungsfehler unverzerrt, d.h. sowohl längen- als auch winkeltreu und daher unmittelbar der geometrischen Anschauung zugänglich. Das Sektormodell eines gekrümmten dreidimensionalen Raums ist analog aufgebaut; an die Stelle der ebenen Flächenstücke treten Klötzchen, deren innere Geometrie euklidisch ist. Im Falle einer gekrümmten Raumzeit sind die Sektoren Raumzeitelemente mit Minkowskigeometrie.

Die Allgemeine Relativitätstheorie beschreibt die Bahnen von Licht und freien Teilchen als Geodäten einer im Allgemeinen gekrümmten Raumzeit. Das Konzept der Geodäte ist deshalb ein wichtiger Punkt jeder Einführung in die Relativitätstheorie. Der vorliegende Beitrag zeigt, wie anhand von Sektormodellen der Begriff der Geodäte eingeführt und Geodäten zeichnerisch ermittelt werden können. An die Stelle der Lösung eines Systems gewöhnlicher Differentialgleichungen tritt die Konstruktion mit dem Lineal. Die Konstruktion der Geodäten entspricht der Beschreibung von Geodäten im Regge-Kalkül (Williams und Ellis 1981) und liefert im Rahmen des Diskretisierungsfehlers quantitativ richtige Resultate. 


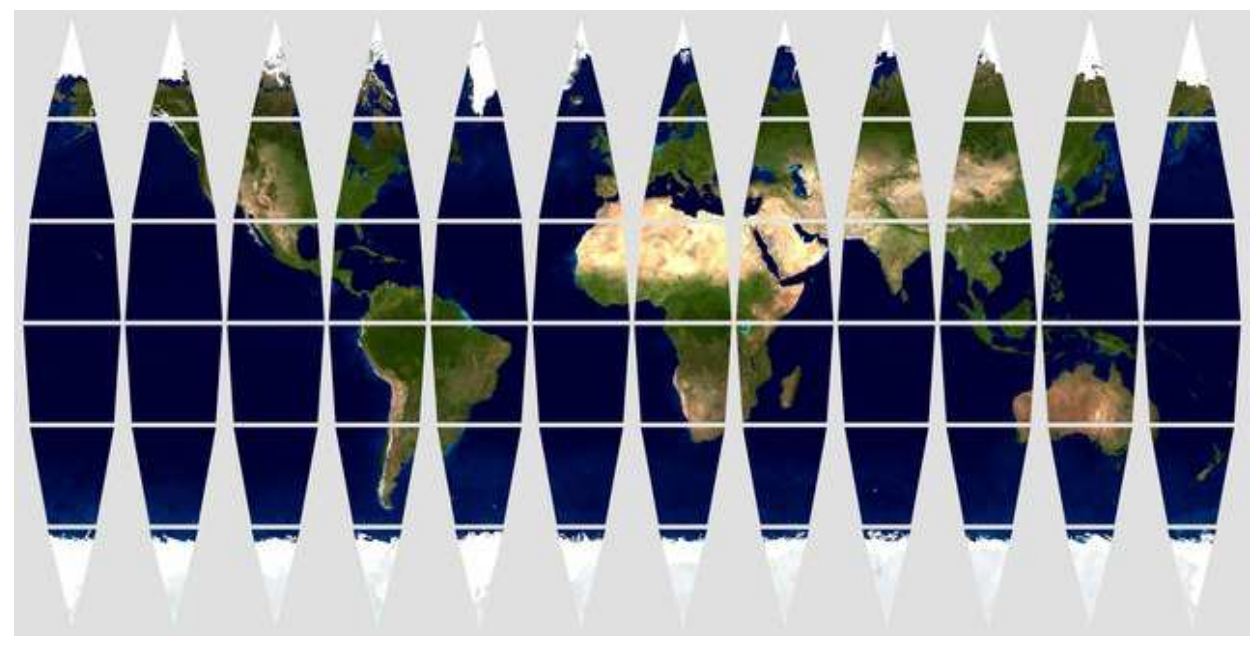

Abbildung 1. Sektormodell der Erdoberfläche. Erdtextur: NASA.

In diesem Beitrag stellen wir einen Workshop zur gravitativen Lichtablenkung vor, den wir in dieser Form mit Schüler/innen sowie mit Studierenden durchführen (Abschnitt 2). In Abschnitt 3 werden die Näherungen diskutiert, die mit der Konstruktion von Geodäten auf Sektormodellen verbunden sind und es wird die erzielbare Genauigkeit untersucht. Fazit und Ausblick folgen in Abschnitt 4 .

\section{Workshop Geodäten und Lichtablenkung}

In diesem Workshop wird zunächst am Beispiel von gekrümmten Flächen der Begriff der Geodäte eingeführt. Es wird dann das Zustandekommen der gravitativen Lichtablenkung verdeutlicht, indem auf einem Sektormodell eines Schwarzen Lochs Geodäten konstruiert werden. Das Schwarze Loch wird als Beispiel gewählt, weil in seiner Nähe relativistische Effekte groß und deshalb in den Zeichnungen klar zu erkennen sind. Als Erweiterung des Workshops wird beschrieben, wie Schüler/innen und Studierende in einem vereinfachten Verfahren selbstständig zweidimensionale Sektormodelle erstellen können. Dies versetzt sie in die Lage, Geodäten einer gegebenen Raumzeit ausgehend von deren Metrik zu untersuchen.

\subsection{Geodäten auf gekrümmten Flächen}

In der Einführung zum Workshop wird erläutert, dass die Allgemeine Relativitätstheorie Lichtwege und Bahnen frei fallender Teilchen als Geodäten beschreibt. Je nach Teilnehmerkreis kann die Bedeutung von Geodäten in der Relativitätstheorie lediglich mitgeteilt oder aber mit Bezug auf das Äquivalenzprinzip näher erläutert werden (z. B. Natário 2011, Kap. 5). Als Vorbereitung für die Bestimmung von Geodäten in der Nähe eines Schwarzen Lochs werden zunächst Geodäten auf gekrümmten Flächen veranschaulicht.

Eine Geodäte auf einer gekrümmten Fläche wird als lokal gerade Linie eingeführt. 


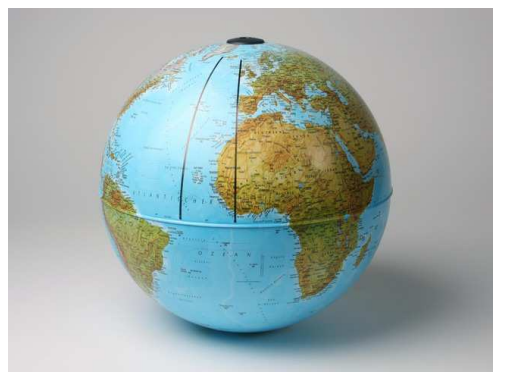

Abbildung 2. Die Geodäten auf der Kugeloberfläche sind die Großkreise.

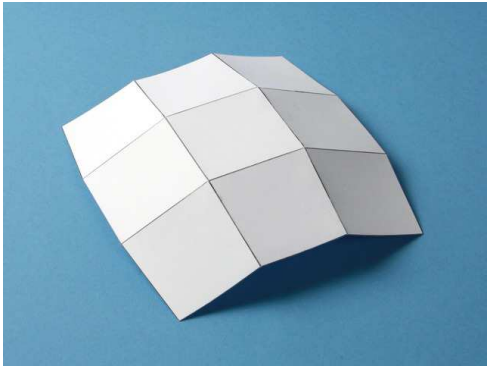

(a)

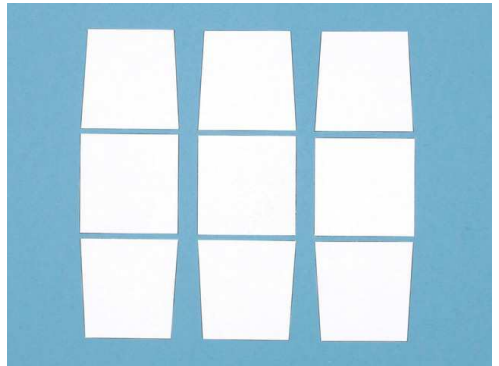

(b)

Abbildung 3. Eine Kugelkalotte wird durch eine Facettenfläche angenähert (a) und als Sektormodell dargestellt (b).

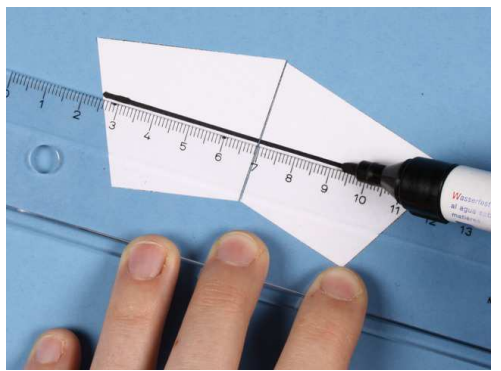

Abbildung 4. Konstruktion einer Geodäte auf einem Sektormodell.

Eine solche Linie behält an jedem Punkt ihre Richtung bei, macht also keinen Bogen und keinen Knick. Es wird ein anschauliches Kriterium dafür angegeben, ob eine Linie eine Geodäte ist: Man denkt sich einen schmalen Streifen aus einem nicht dehnbaren Material längs seiner Mittellinie auf die zu untersuchende Linie geklebt. Falls die Linie einen Bogen macht, reißt der Streifen auf der Außenseite ein und wirft auf der Innenseite Falten - dies zeigt an, dass es sich nicht um eine Geodäte handelt.

Als erstes Beispiel dient die Oberfläche einer Kugel (Abb. 2). Es wird eine Linie betrachtet, die am Äquator in Richtung Nordpol startet und lokal gerade verläuft. Sie liegt offensichtlich auf einem Längenkreis. Längenkreise, allgemeiner alle Großkreise, sind also Geodäten auf der Kugeloberfläche. Abb. 2 illustriert eine charakteristische Eigenschaft dieser Geodäten: Zwei Längenkreise sind am Äquator parallel; in ihrem weiteren Verlauf zum Pol hin nähern sie sich einander an. Allgemein formuliert heißt 


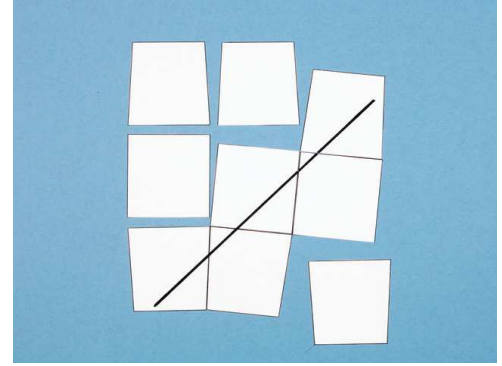

(a)

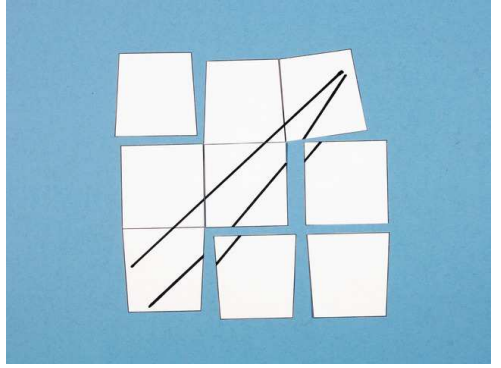

(b)

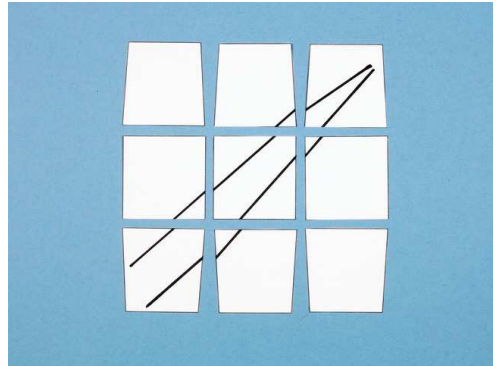

(c)

Abbildung 5. Geodäten auf dem Sektormodell einer Kugelkalotte. Die Sektoren sind in (a) längs der unteren Geodäte aneinandergelegt und in (b) längs der oberen. Im linken unteren Sektor verlaufen die beiden Geodäten parallel, nach rechts nähern sie sich einander an ((b), (c)).

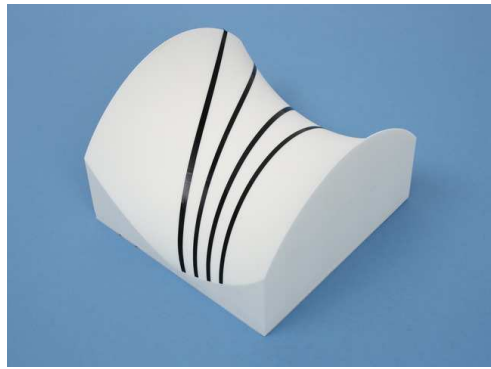

(a)

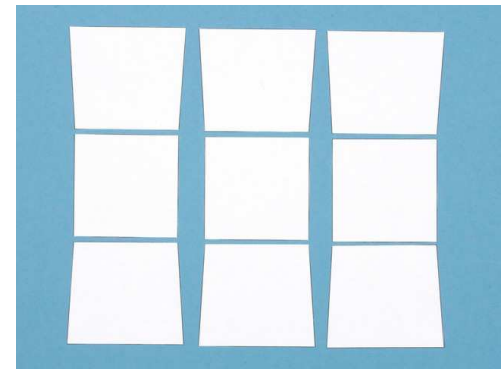

(c)

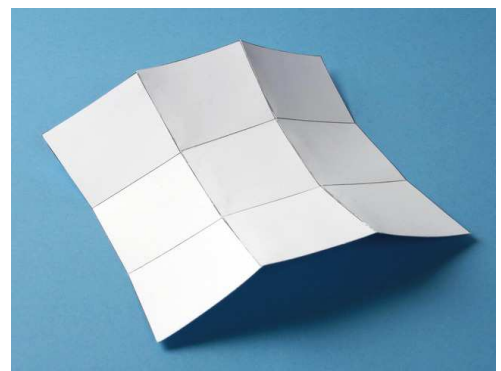

(b)

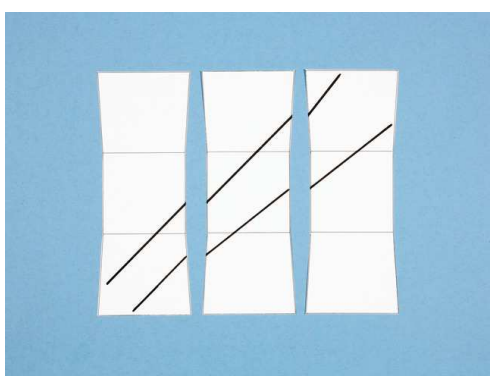

(d)

Abbildung 6. Aus einer Sattelfläche (a) wird ein Ausschnitt über die Annäherung als Facettenfläche (b) als Sektormodell dargestellt (c); parallel startende Geodäten laufen auseinander $((\mathrm{a}),(\mathrm{d}))$.

das für die Kugeloberfläche, dass parallel startende Geodäten aufeinander zu laufen.

Im nächsten Schritt wird gezeigt, wie man diese Eigenschaft von Geodäten der Kugeloberfläche mithilfe eines Sektormodells gewinnen kann. Eine Kugelkalotte wird durch eine Facettenfläche angenähert (Abb. 3(a)); die Facetten werden als Sektormodell ausgelegt (Abb. 3(b)). Nun soll eine Geodäte quer durch das Sektormodell gezeichnet werden. Innerhalb eines Sektors, der ja eben ist, ist die Geodäte eine gerade Linie. Wenn die Linie den Rand eines Sektors erreicht, wird sie in den Nachbarsektor fortgesetzt. Wie das zu geschehen hat, folgt aus der Definition der Geodäte: lokal gerade (Abb. 4). Die 


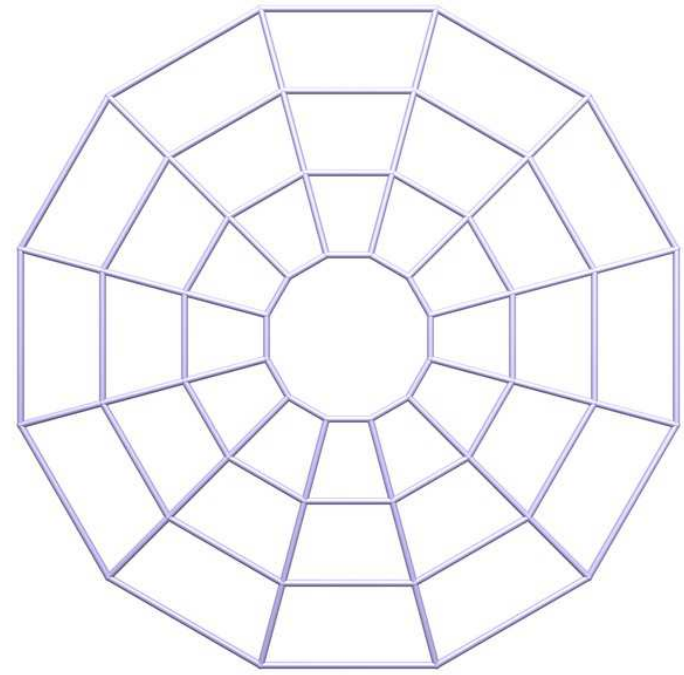

(a)

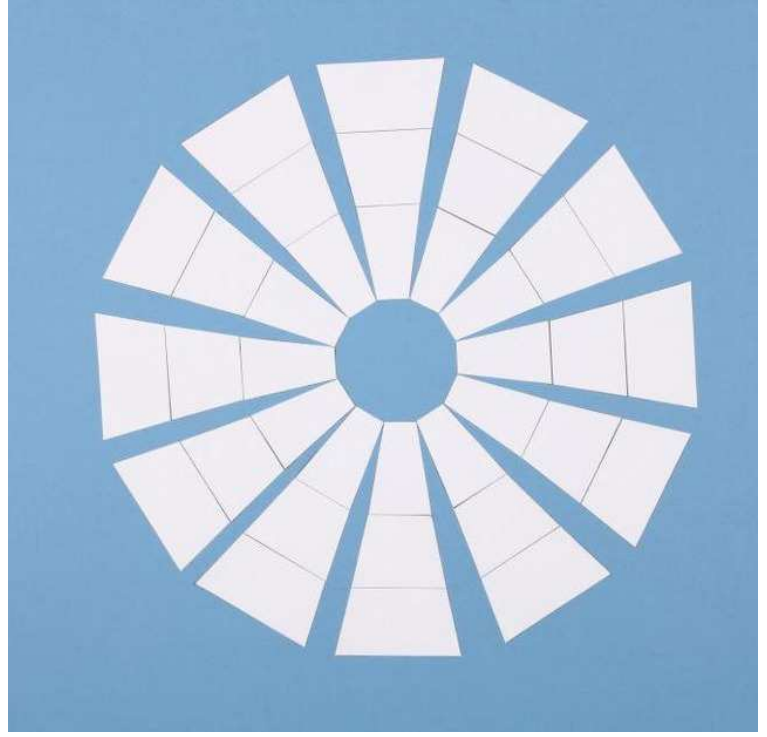

(b)

Abbildung 7. Ein Gedankenexperiment zum Sektormodell für die Äquatorfläche eines Schwarzen Lochs: Um das Schwarze Loch wird ein Gittergerüst nach dem in (a) gezeigten Schema errichtet. Für jede Zelle werden die Längen der sie umschließenden vier Stäbe abgemessen; aus diesen Daten werden maßstabsgerechte Sektoren aus Papier konstruiert. Es resultiert das Sektormodell des Rings um das Schwarze Loch (b).

beiden benachbarten Sektoren werden an ihrer gemeinsamen Kante zusammengelegt und die Linie wird über die Sektorgrenze hinweg geradlinig fortgesetzt. Auf diese Weise wird die Geodäte quer durch das Sektormodell gezeichnet (Abb. 5(a)). Es wird dann eine zweite Geodäte hinzugefügt, die im linken unteren Sektor parallel zur ersten verläuft (Abb. 5(b)). Man erkennt, dass sich die beiden parallel startenden Geodäten annähern (Abb. 5)(b), (c)).

Als zweites Beispiel dient eine Sattelfläche. Aufgeklebte Klebestreifen zeigen, dass parallel startende Geodäten sich voneinander entfernen (Abb. 6(a)). Die Annäherung eines Ausschnitts der Fläche durch eine Facettenfläche (Abb. 6(b)) führt zu einem Sektormodell (Abb. 6(c)). Es werden zwei Geodäten eingezeichnet, die in der linken unteren Ecke des Modells parallel verlaufen; diese entfernen sich voneinander (Abb. 6(d)).

An den beiden Beispielen wird deutlich, dass die Sektormodelle gekrümmter Flächen dazu geeignet sind, die Eigenschaften von Geodäten auf den Flächen zu untersuchen.

\subsection{Geodäten in der Nähe eines Schwarzen Lochs}

Im zweiten Teil des Workshops wird zunächst ein Sektormodell vorgestellt, das es erlaubt Geodäten in der Nähe eines Schwarzen Lochs zu konstruieren. Das Sektormodell stellt eine Symmetrieebene des Schwarzen Lochs dar; diese wird im Folgenden als 


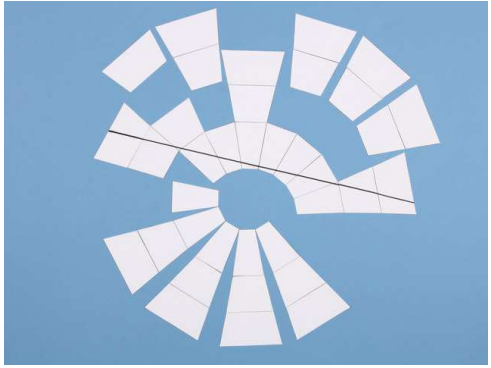

(a)

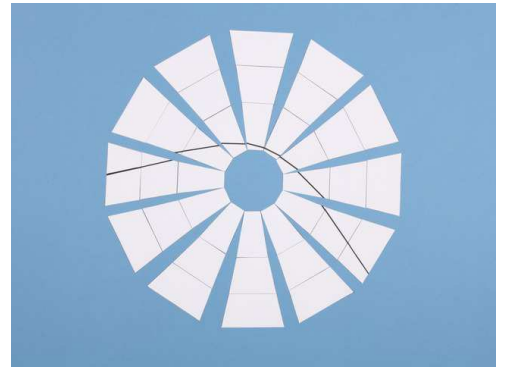

(b)

Abbildung 8. Eine Geodäte auf dem Sektormodell der Äquatorfläche eines Schwarzen Lochs. Die Linie ist lokal gerade; die beiden Enden zeigen in unterschiedliche Richtungen. Die Sektoren sind in (a) längs der Geodäte aneinandergelegt und in (b) symmetrisch angeordnet.

Äquatorebene bezeichnet

Das Sektormodell wird eingeführt, indem im Gedankenexperiment seine „Entstehung" beschrieben wird: Ein Raumschiff wird in die Nähe eines Schwarzen Lochs geschickt, um die Geometrie des Raums zu vermessen. Dazu wird um das Schwarze Loch nach dem in Abb. 7(a) dargestellten Schema ein Gittergerüst errichtet. In Art eines Radnetzes, das auf das Schwarze Loch zentriert ist, werden starre Stäbe in der Äquatorebene des Schwarzen Lochs angeordnet. Das ganze Gerüst befindet sich außerhalb des Ereignishorizonts, da im Inneren des Schwarzen Lochs eine solche statische Struktur nicht möglich ist § Das Gittergerüst wird vermessen: Jede einzelne Gitterzelle ist von vier Stäben umschlossen. Deren Längen werden bestimmt und zur Erde übermittelt. Dort wird die Gitterzelle verkleinert als Sektor dargestellt. Alle Sektoren zusammen bilden das maßstabsgetreue Modell eines Rings um das Schwarze Loch (Abb. 7(b)). Sie lassen sich allerdings nicht lückenlos zu einem Ring zusammenschieben. Dies zeigt an, dass die Äquatorebene des Schwarzen Lochs eine andere Geometrie hat als die ebene Fläche, auf der die Sektoren ausgelegt sind. Die Äquatorebene des Schwarzen Lochs ist Teil eines gekrümmten Raums; die Unterlage des Modells ist eine Ebene im euklidischen Raum. Könnte man ein Schwarzes Loch der passenden Größe in die Mitte des Modells setzen, dann würden die Flächenstücke so wie sie sind lückenlos zusammenpassen. Für die online verfügbare Vorlage (Zahn und Kraus 2018) hat das zu dem Modell passende Schwarze Loch ungefähr die dreifache Erdmasse.

Alternativ kann das Sektormodell mit dem Workshop über gekrümmte Räume aus Teil I eingeführt werden. Dort wird ein Sektormodell des dreidimensionalen gekrümmten Raums um ein Schwarzes Loch vorgestellt (Abb. 5(b) in Teil I), dessen Äquatorfläche genau das in Abb. 7(b) gezeigte Modell ist (in Abb. 5(b) von Teil I: die grünen, annähernd horizontal ausgerichteten Seiten der Klötzchen).

$\ddagger$ Wir betrachten ein nichtrotierendes Schwarzes Loch. Es ist kugelsymmetrisch, weshalb jede Geodäte in einer Ebene verläuft, die eine Symmetrieebene des Schwarzen Lochs darstellt.

$\S$ Das Gitter überdeckt den Bereich von 1,25 bis 5 Schwarzschildradien in der Schwarzschildschen Radialkoordinate, s. Abschnitt 2.4.2. 


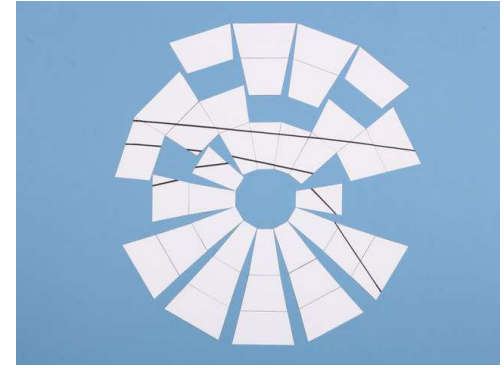

(a)

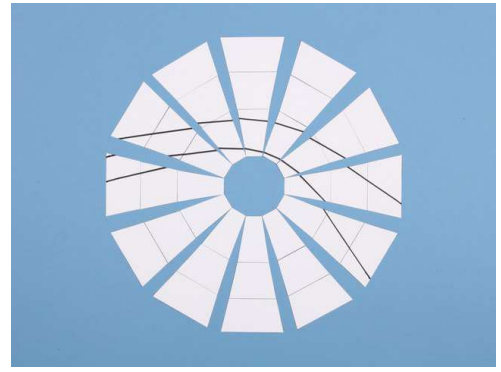

(b)

Abbildung 9. Zu der in Abb. 8 gezeigten Geodäte wird eine zweite hinzugefügt, die links außen parallel zur ersten verläuft: Die innere Geodäte wird stärker abgelenkt; die beiden Geodäten laufen auseinander. Die Sektoren sind in (a) längs der zweiten Geodäte aneinandergelegt und in (b) symmetrisch angeordnet.

Das Sektormodell von Abb. 7(b) wird für den Workshop vorbereitet, indem die Sektoren aus Papier ausgeschnitten und mit Sprühkleber (Kleber für wiederlösbare und wiederverklebbare Verbindungen) auf Karton fixiert werden $\|$. Dann wird das Sektormodell dazu verwendet, Geodäten in der Nähe eines Schwarzen Lochs zu untersuchen. Zunächst wird eine einzelne Geodäte quer durch das Sektormodell gezeichnet. Wie oben am Beispiel gekrümmter Flächen beschrieben, geschieht dies durch Aneinanderlegen benachbarter Sektoren und Zeichnen einer geraden Linie (Abb 8(a)). Man erkennt, dass die beiden Enden der Linie in unterschiedliche Richtungen zeigen (Abb 8(b)). Eine Linie, die nah an einem Schwarzen Loch vorbeiführt und dabei in jedem Punkt ihre Richtung beibehält, hat also „weit nach" dem Schwarzen Loch eine andere Richtung als „weit davor“. Die Konstruktion verdeutlicht das Prinzip der Lichtablenkung im Schwerefeld: Licht breitet sich lokal geradlinig aus; wenn es einen Bereich gekrümmter Raumzeit durchquert, ist die Ausbreitungsrichtung hinterher anders als vorher.

Um die Aussagekraft dieser Konstruktion auf dem Sektormodell einzuschätzen, sind zwei Dinge zu bedenken. Zum einen sind die auf Sektormodellen konstruierten Geodäten quantitativ richtig. Wenn man die Bedingung des lokal geraden Verlaufs mathematisch formuliert, erhält man die Geodätengleichung (Weinberg 1972, S. 70 ff). Die konstruierte Geodäte ist eine Lösung dieser Gleichung. Da das Sektormodell den gekrümmten Raum näherungsweise darstellt, ist auch die gezeichnete Geodäte eine Näherungslösung. Durch eine entsprechend feine Unterteilung können Geodäten aber prinzipiell auch mit hoher Genauigkeit konstruiert werden (s. Abschnitt 3). Zum anderen muss bedacht werden, dass die konstruierte Linie zwar eine Geodäte ist, aber dennoch keinen Lichtstrahl darstellt. Die gezeichnete Geodäte ist rein räumlich. Licht jedoch breitet sich in Raum und Zeit aus, was bedeutet, dass Lichtwege raumzeitliche Geodäten sind. Die rein räumliche Geodäte illustriert also im Sinne einer Analogie, wie Lichtablenkung prinzipiell zustandekommt.

\| S. Abschnitt 2.3 für ein Verfahren, das ohne Aufkleben von Sektoren auskommt. 


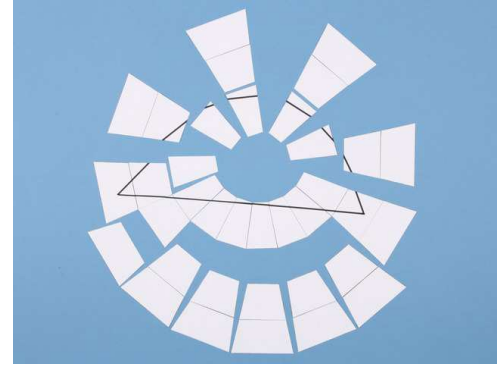

(a)

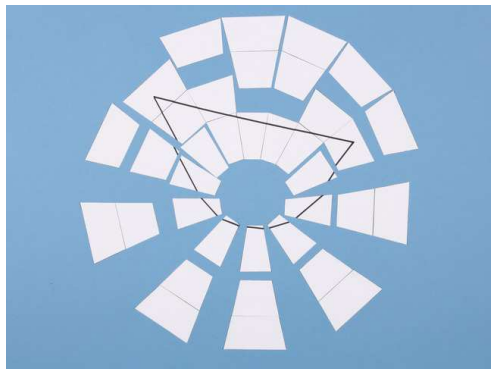

(b)

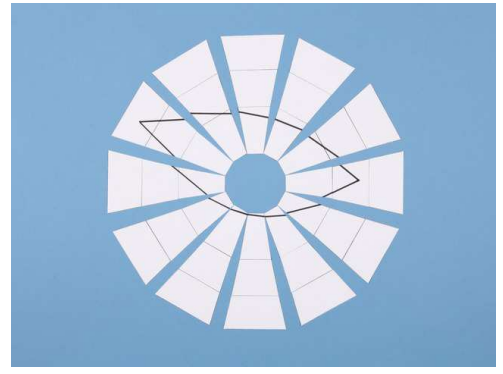

(c)

Abbildung 10. Zwei Geodäten bilden ein Zweieck. Dies illustriert die Entstehung von Doppelbildern durch Lichtablenkung: Licht einer Quelle erreicht den Beobachter auf zwei verschiedenen Wegen. Die Sektoren sind in (a) und (b) jeweils längs einer der Geodäten aneinandergelegt und in (c) symmetrisch angeordnet.

Auch wenn räumliche Geodäten nicht identisch mit Lichtstrahlen sind, ist es instruktiv, an ihnen Eigenschaften von Geodäten aufzuzeigen. So kann man eine zweite Geodäte konstruieren, die in der Nähe der ersten und parallel zu ihr beginnt (Abb. 9). Diejenige der beiden Geodäten, die dem Schwarzen Loch näher kommt, wird stärker abgelenkt; die beiden Geodäten laufen auseinander. Schließlich kann man zwei Geodäten konstruieren, die vom selben Punkt ausgehend auf verschiedenen Seiten am Schwarzen Loch vorbeiführen und sich wieder treffen (Abb. 10). Man kann also aus Geodäten ein Zweieck bilden. Übertragen auf Lichtstrahlen zeigt diese Konstruktion, wie Doppelbilder zustandekommen.

\subsection{Konstruktion von Geodäten mit Transfersektoren}

Für die Abbildungen 8, 9 und 10 wurden die Sektoren ausgeschnitten und nach Bedarf längs einer Geodäte oder aber in symmetrischer Anordnung ausgelegt. Das hat den Vorteil, dass man jede Geodäte für sich als gerade Linie zeigen kann. Die Konstruktion der Geodäten kann man aber einfacher und schneller durchführen, wenn man auf das Ausschneiden der Sektoren verzichtet. Dazu wird die in Abb. 11(a) gezeigte Vorlage mit symmetrischer Anordnung und Randmarkierungen verwendet. Ausgeschnitten wird nur eine einzelne zusätzliche Spalte (Abb. 11(b)); dies sind die sogenannten Transfersektoren. Man beginnt nun mit dem Zeichnen einer Geodäte auf der symmetrischen Vorlage, bis man an den Rand einer Spalte gelangt (Abb. 12(a)). Dann wird die Transferspalte so positioniert, dass an der Kante mit dem Durchstoßpunkt der passende Transfersektor anliegt, und die Linie wird geradlinig über die Spalte der Transfersektoren fortgesetzt (Abb. 12(b)). Von den Transfersektoren wird die Linie auf die Nachbarspalte der Vorlage übertragen (Abb. 12(c)). Dieses Verfahren wird bis zum gewünschten Endpunkt fortgesetzt. In dem in Abb. 11(a) gezeigten Sektormodell sind die Ränder der Sektoren mit äquidistanten Markierungen versehen, die das Übertragen der Geradenstücke erleichtern. Die in Abb. 11 gezeigte Vorlage ist online verfügbar (Zahn und Kraus 2018). 


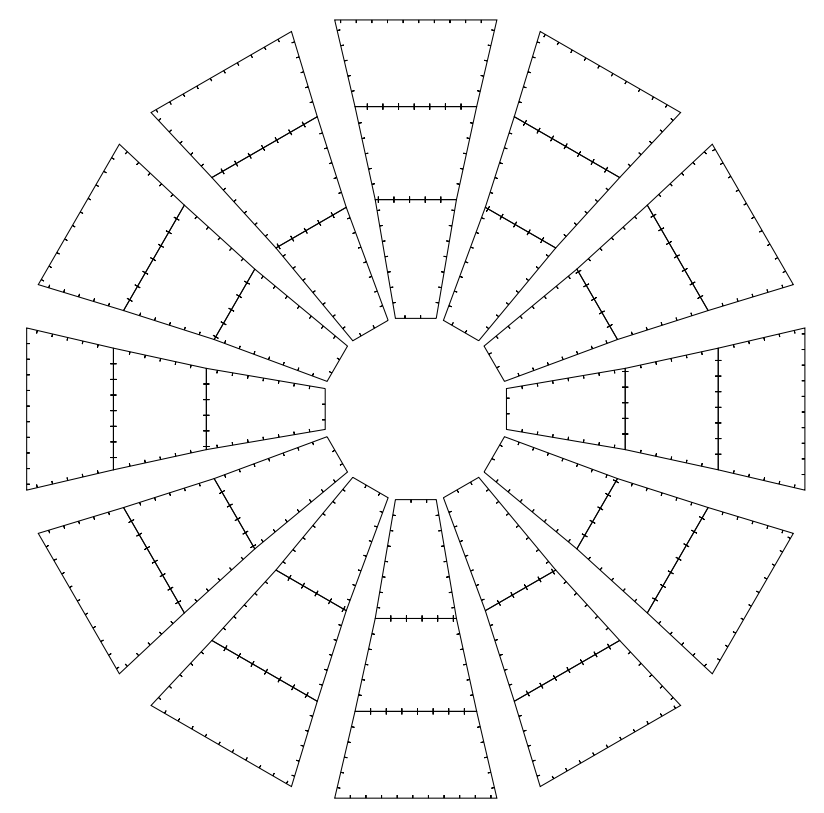

(a)

Abbildung 11. Vorlage für die Konstruktion von Geodäten in der Nähe eines Schwarzen Lochs. Die Vorlage besteht aus dem Sektormodell der Äquatorfläche als symmetrisch ausgelegtem Gesamtmodell mit Randmarkierungen (a) und einer Spalte von Transfersektoren (b). Der Schwarzschildradius $r_{\mathrm{S}}$ des Schwarzen Lochs ist als Balken markiert.

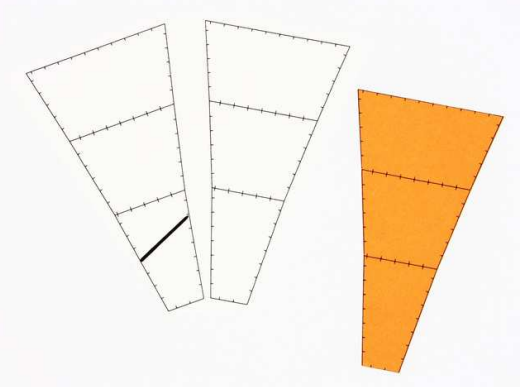

(a)

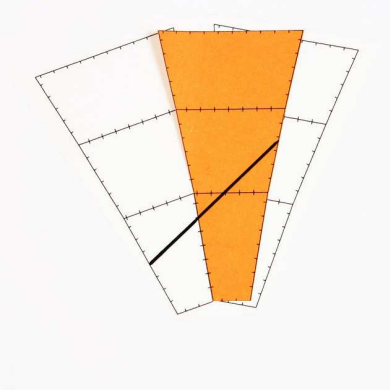

(b)

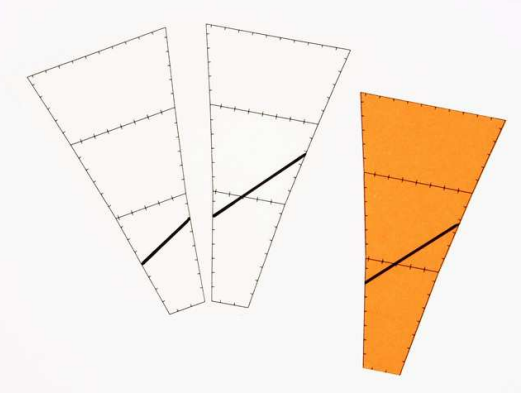

(c)

Abbildung 12. Konstruktion von Geodäten mit Transfersektoren (farbig markiert). Die Geodäte wird bis zum Rand der Spalte gezeichnet (a), nach Anlegen des passenden Transfersektors auf der Transferspalte fortgesetzt (b) und von dort auf die Nachbarspalte übertragen (c). 


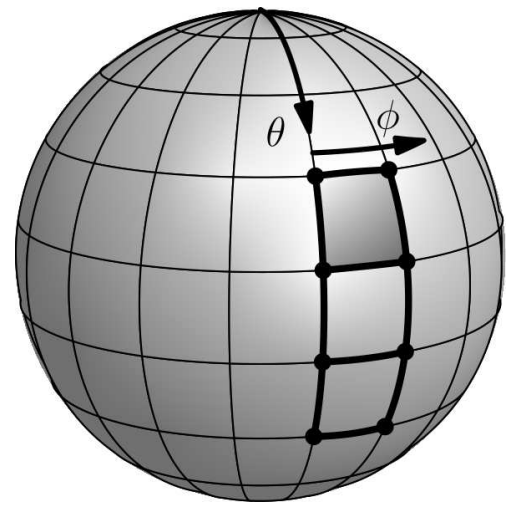

(a)

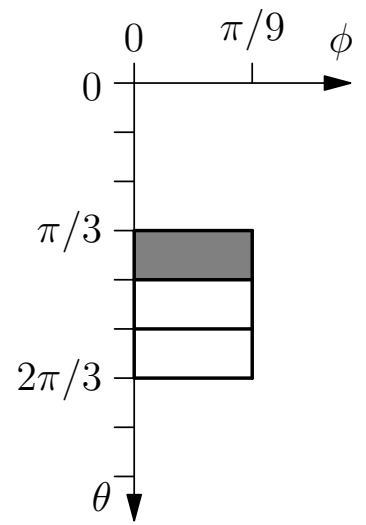

(b)

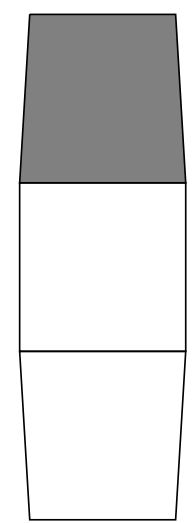

(c)

\begin{abstract}
Abbildung 13. (a) Die Oberfläche einer Kugel wird mit Polarkoordinaten $\theta, \phi$ beschrieben und in Flächenstücke mit Winkelausdehnung $20 \mathrm{Grad}$ auf $20 \mathrm{Grad}$ unterteilt. (b) Drei Flächenstücke im $\phi$ - $\theta$-Koordinatenraum. (c) Die zugehörigen Sektoren. Sie bilden eine Spalte des in Abb. 3(b) gezeigten Modells. Zur leichteren Zuordnung ist in allen drei Teilbildern ein und derselbe Sektor grau markiert.
\end{abstract}

\title{
2.4. Erstellung von Sektormodellen
}

Ein Workshop kann wie oben beschrieben mit vorgegebenen Sektormodellen durchgeführt werden. Dies ist die einfachste und die kürzeste Variante. Ihr volles Potenzial als Werkzeug zur Untersuchung gekrümmter Räume entfalten Sektormodelle aber dann, wenn sie von den Teilnehmer/innen selbst berechnet und konstruiert werden. Dies versetzt die Teilnehmer/innen in die Lage, andere gekrümmte Räume selbstständig auf die gleiche Weise zu untersuchen und beispielsweise zu einer gegebenen Metrik Geodäten zu bestimmen. Dabei werden Aufstellen und Lösen der Geodätengleichung ersetzt durch Erstellung des Sektormodells und zeichnerische Geodätenkonstruktion.

Im folgenden Abschnitt wird gezeigt, wie man am Beispiel der Kugeloberfläche die Berechnung von Sektormodellen einführen kann. Das Vorgehen wird anschließend auf die Berechnung des Sektormodells der Äquatorfläche angewandt.

2.4.1. Erstellung des Sektormodells einer Kugeloberfläche. An diesem Beispiel wird das prinzipielle Vorgehen bei der Erstellung von Sektormodellen eingeführt. Voraussetzung ist der Begriff der Metrik als einer Funktion, die den Koordinaten zweier nahe benachbarter Punkte den Abstand dieser Punkte zuordnet. Die Metrik kann ausgehend von krummlinigen Koordinaten auf elementare Weise eingeführt werden (z.B. Kraus und Zahn 2016; Hartle 2003, S. 21 f; Natário 2011, S. 35 f).

Ausgangspunkt der Berechnung ist die Metrik der Kugeloberfläche in den üblichen Polarkoordinaten $\theta, \phi$ (Abb. [13(a)):

$$
\mathrm{d} s^{2}=R^{2} \mathrm{~d} \theta^{2}+R^{2} \sin ^{2} \theta \mathrm{d} \phi^{2},
$$

wobei $R$ der Radius der Kugel ist (für eine elementare Herleitung, die im Workshop genutzt werden kann, siehe z. B. Hartle 2003, S. 23 f; Natário 2011, S. 37 ff). 


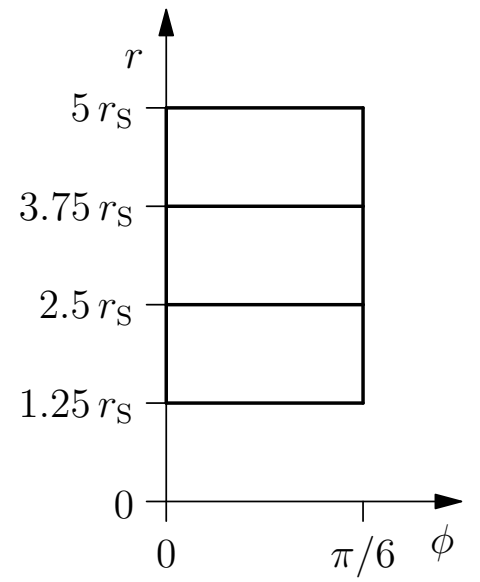

(a)

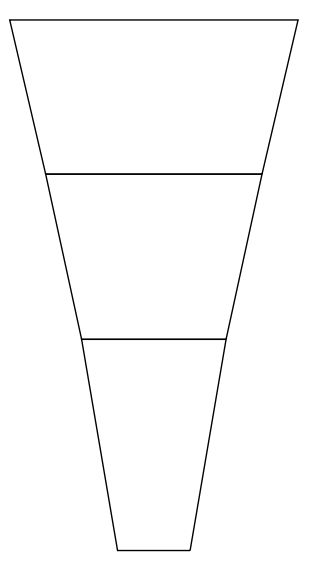

(b)

Abbildung 14. Zur Erstellung des Sektormodells der Äquatorfläche eines Schwarzen Lochs. (a) Die drei Flächenstücke einer Spalte im $\phi$-r-Koordinatenraum. (b) Die zugehörigen Sektoren.

Die Erstellung des Sektormodells erfolgt in drei Schritten. Im ersten Schritt wird die Kugeloberfläche in Flächenstücke unterteilt, die durch ihre Eckpunkte definiert sind. In dem hier betrachteten Beispiel sind die Flächenstücke Vierecke, deren Eckpunkte in den Winkelkoordinaten $\theta$ und $\phi$ jeweils Abstände von $20 \mathrm{Grad}(\pi / 9)$ haben (Abb. 13(a), (b)). Im zweiten Schritt werden die Kantenlängen der Flächenstücke berechnet. Dies geschieht näherungsweise, um die Berechnung einfach zu halten. Für jede Kante wird der Abstand zwischen den beiden Endpunkten bestimmt, indem man die Endpunkte als nahe benachbarte Punkte im Sinne der Definition der Metrik behandelt. Man erhält für die Kanten zwischen zwei Punkten auf demselben Längenkreis die Länge

$$
\Delta s=R \Delta \theta \quad(\Delta \phi=0),
$$

im konkreten Beispiel $\Delta s=R \pi / 9$. Für die Kanten zwischen zwei Punkten auf demselben Breitenkreis erhält man

$$
\Delta s=R \sin \theta \Delta \phi \quad(\Delta \theta=0),
$$

abhängig vom Winkel $\theta$ des Breitenkreises. Für die Sektormodelle in den Abbildungen und Online-Ressourcen werden die Kantenlängen als Längen der Geodäten zwischen den Eckpunkten berechnet (s. Teil I). Der Unterschied zwischen den genäherten und den exakten Kantenlängen beträgt bei diesem Beispiel maximal 0,13\%.

Im dritten Schritt werden aus den Kantenlängen ebene Flächenstücke konstruiert. In dem hier betrachteten Beispiel haben die Flächenstücke auf der Kugel Spiegelsymmetrie; die ebenen Flächenstücke werden mit der gleichen Symmetrieeigenschaft als symmetrische Trapeze konstruiert (Abb. 13(c)). 
2.4.2. Erstellung des Sektormodells der Äquatorfläche eines Schwarzen Lochs. Ausgangspunkt der Berechnung ist die Metrik der Äquatorebene eines Schwarzen Lochs

$$
\mathrm{d} s^{2}=\frac{1}{1-r_{\mathrm{S}} / r} \mathrm{~d} r^{2}+r^{2} \mathrm{~d} \phi^{2}
$$

in den üblichen Schwarzschildkoordinaten $r$ und $\phi$. Hier ist $r_{\mathrm{S}}=2 G M / c^{2}$ der Schwarzschildradius des Schwarzen Lochs mit Masse $M, G$ die Newtonsche Gravitationskonstante und $c$ die Lichtgeschwindigkeit. Das Sektormodell stellt einen ringförmigen Ausschnitt der Äquatorebene dar. Der Innenrand liegt bei $r=1,25 r_{\mathrm{S}}$, der Außenrand bei $r=5 r_{\mathrm{S}}$. Der Azimutwinkel $\phi$ nimmt Werte zwischen null und $2 \pi$ an.

Zunächst wird der Ring in Flächenstücke unterteilt. Dazu wird der $\phi$-Bereich in 12 Abschnitte von je $\pi / 6$ aufgeteilt. Da die Metrik nicht von der Koordinate $\phi$ abhängt, braucht nur einer der 12 Abschnitte berechnet zu werden; man erhält 12 identische Spalten, die im Kreis angeordnet werden. Der $r$-Bereich wird in drei Abschnitte der Koordinatenlänge 1,25 $r_{\mathrm{S}}$ eingeteilt (Abb. 14(a)). Im zweiten Schritt werden die Kantenlängen der drei in Abb. 14(a) gezeigten Vierecke berechnet. Für den Abstand von Eckpunkten mit gleicher $r$-Koordinate erhält man mithilfe der Metrik

$$
\Delta s=r \Delta \phi \quad(\Delta r=0) .
$$

Bei der Abstandsberechnung von Eckpunkten mit gleicher $\phi$-Koordinate kommt der erste Term der Metrik zum Tragen. Er enthält den Metrikkoeffizienten $1 /\left(1-r_{\mathrm{S}} / r\right)$, der von $r$ abhängt, sich also längs der Kante ändert. Hier machen wir eine weitere Näherung und verwenden den Metrikkoeffizienten an der mittleren $r$-Koordinate $r_{\mathrm{m}}$ der Kante:

$$
\Delta s=\sqrt{\frac{1}{\left(1-r_{\mathrm{S}} / r_{\mathrm{m}}\right)}} \Delta r \quad(\Delta \phi=0),
$$

wobei $r_{\mathrm{m}}=\left(r_{1}+r_{2}\right) / 2$ mit den Koordinaten $r_{1}$ und $r_{2}$ der zugehörigen Eckpunkte. Für die Abbildungen und Online-Ressourcen werden die Kantenlängen als Längen der Geodäten zwischen den Eckpunkten numerisch berechnet. Die Abweichung der vereinfacht berechneten Kantenlängen ist am größten für die innerste radiale Kante und beträgt hier $5,4 \%$.

Im dritten Schritt werden die Vierecke konstruiert. Die Aufteilung des Rings durch radiale Schnitte erzeugt Flächenelemente mit Spiegelsymmetrie (Abb. 7(a)); dieser Symmetrie entsprechend werden die Flächenstücke als symmetrische Trapeze konstruiert. Abb. 14 stellt die drei Sektoren einer Spalte den zugehörigen Vierecken im $\phi$-r-Koordinatenraum gegenüber. Das vollständige Sektormodell mit zwölf Spalten ist in Abb. 11 dargestellt.

\subsection{Geodäten vs. Krümmung}

Den Zusammenhang zwischen der Krümmung einer Fläche und dem Verlauf von Geodäten kann man zum Thema machen, wenn man zusätzlich zu dem oben geschilderten Workshop über Geodäten auch den in Teil I (Abschnitt 2) beschriebenen Workshop über Krümmung durchführt. In Teil I werden die Kugeloberfläche und 


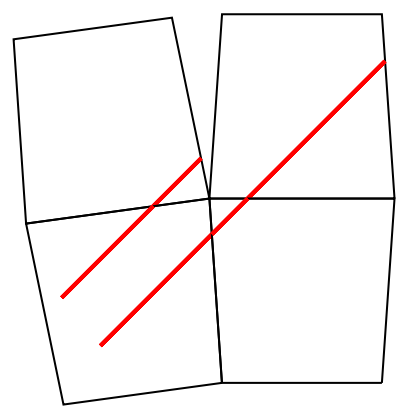

(a)

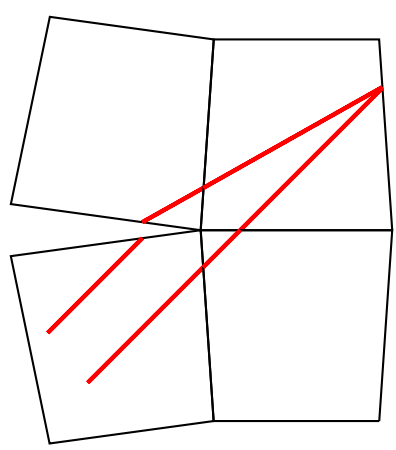

(b)

Abbildung 15. Zwei zunächst parallele Geodäten (a) führen auf verschiedenen Seiten an einem Vertex vorbei und sind anschließend um den Defizitwinkel zueinander geneigt (b).

die Sattelfläche als Prototypen für Flächen mit positiver bzw. negativer Krümmung vorgestellt. Es wird verdeutlicht, dass der Defizitwinkel im Sektormodell ein Kriterium für die Krümmung ist: Positive Krümmung wird durch einen positiven Defizitwinkel angezeigt und vice versa 4

Anhand von Sektormodellen kann man aufzeigen, dass der Verlauf benachbarter Geodäten ebenfalls ein Kriterium für die Krümmung darstellt. Abb. 15 stellt den Verlauf von benachbarten Geodäten in der Nähe eines einzelnen Vertex mit positivem Defizitwinkel dar. Zwei Geodäten, die vor dem Vertex parallel verlaufen und auf verschiedenen Seiten an dem Vertex vorbeiführen (Abb. 15)(a)), laufen nach dem Vertex aufeinander zu (Abb. 15(b)). Der Winkel, den die beiden Richtungen nach dem Vertex einschließen, ist nach Konstruktion der Defizitwinkel.

Parallel startende Geodäten zeigen also positive Krümmung an, wenn sie aufeinander zu laufen. Umgekehrt zeigen sie negative Krümmung an, wenn sie auseinander laufen. Zwei Beispiele für dieses Kriterium gibt Abschnitt 2.1 mit Geodäten auf der Kugeloberfläche (Abb. 5(c)) und der Sattelfläche (Abb. 6(d)). Angewandt auf die Äquatorebene eines Schwarzen Lochs schließt man aus dem Auseinanderlaufen von parallel startenden Geodäten (Abb. 9) auf eine negative Krümmung.

Die obige Überlegung ist eine Veranschaulichung für die Gleichung der geodätischen Abweichung

$$
\left(\nabla_{\mathbf{u}} \nabla_{\mathbf{u}} \mathbf{D}\right)^{i}=-R_{j k l}^{i} u^{j} D^{k} u^{l}
$$

für zwei Geodäten $x^{i}(\lambda)$ und $x^{i}(\lambda)+D^{i}(\lambda)$ mit $u^{i}=d x^{i} / d \lambda$ und dem Riemannschen Krümmungstensor $R_{j k l}^{i}$. Im Sektormodell werden die Komponenten des Riemannschen Krümmungstensors durch die Defizitwinkel dargestellt (Teil I, Abschnitt 3) und Abb. 15

I Der Defizitwinkel ist positiv, wenn nach Zusammenschieben aller an einen Eckpunkt angrenzenden Sektoren eine keilförmige Lücke verbleibt (ein Beispiel gibt Abb. 15). Er ist negativ, wenn nach Zusammenschieben aller an einen Eckpunkt angrenzenden Sektoren bis auf einen die verbleibende Lücke zu klein ist für den letzten Sektor. 
zeigt bildlich, wie diese sich auf die Änderung des Abstands benachbarter Geodäten auswirken.

\section{Die Genauigkeit von Geodäten auf Sektormodellen}

Im Regge-Kalkül werden Geodäten als Geradenstücke in den ungekrümmten Sektoren beschrieben (Williams und Ellis 1981, 1984, Brewin 1993). Diese Darstellung wird auf den Sektormodellen zeichnerisch umgesetzt. Die so konstruierten Geodäten sind also grundsätzlich quantitativ korrekt. Ihre Genauigkeit hängt allerdings von der Auflösung der Sektormodelle ab. Für die Workshops wird die Auflösung bewusst grob gewählt, damit die Modelle gut handhabbar sind. In diesem Abschnitt wird durch den Vergleich mit numerisch berechneten Geodäten untersucht, welche Genauigkeit mit der zeichnerischen Methode erreicht wird. Für den Vergleich werden zwei Sektormodelle der Äquatorebene eines Schwarzen Lochs verwendet, die beide den Bereich zwischen $r=1,25 r_{\mathrm{S}}$ und $r=13,75 r_{\mathrm{S}}$ überdecken. Das erste hat die Auflösung des im Workshop verwendeten Sektormodells $\left(\Delta r=1,25 r_{\mathrm{S}}, \Delta \phi=\pi / 6\right)$; es besteht aus 10 Ringen zu je 12 Sektoren (Abb. 16(a)). Das zweite hat in jeder Koordinatenrichtung die vierfache Auflösung $\left(\Delta r=0,3125 r_{\mathrm{S}}, \Delta \phi=\pi / 24\right)$ und besteht somit aus 40 Ringen zu je 48 Sektoren (Abb. 16(b)). In Abb. 16 sind die im Regge-Kalkül bestimmten Geodäten und die numerischen Lösungen der Geodätengleichung im Vergleich dargestellt. Dazu werden die berechneten Bahnen auf dem Sektormodell dargestellt. Die Abbildung der in Schwarzschildkoordinaten gegebenen Bahnpunkte auf Punkte im Sektormodell erfolgt durch Interpolation (Hormann 2005). Für einen quantitativen Vergleich wurde auf denselben beiden Sektormodellen der Ablenkwinkel als Funktion des Stoßparameters bestimmt und mit den aus der Geodätengleichung durch Integration bestimmten Werten verglichen (Abb. 17). Auf den Sektormodellen wurden dabei für jeden Stoßparameter zehn Geodäten konstruiert, die in $\phi$-Richtung gegeneinander verdreht sind, so dass sie unterschiedliche Lagen bzgl. der Sektorgrenzen haben. Man erkennt, dass für die gröbere Diskretisierung die Übereinstimmung von Geodäten mit geringer Ablenkung gut ist, dass bei Geodäten mit starker Ablenkung aber erhebliche Abweichungen auftreten können (Abb. 16(a), 17(a)). Für das Sektormodell mit der höheren Auflösung ist die Übereinstimmung generell gut (Abb. 16(b), 17(b)). Die Genauigkeit auf dem im Workshop eingesetzten Sektormodell ist für qualitative Betrachtungen völlig zufriedenstellend.

\section{Fazit und Ausblick}

\subsection{Zusammenfassung und didaktische Anmerkungen}

Wir haben gezeigt, auf welche Weise man Sektormodelle als Werkzeuge zur Bestimmung von Geodäten einsetzen kann. Dies vermittelt einerseits ein anschauliches Verständnis und ermöglicht andererseits die Ermittlung von Geodäten mit zeichnerischen Mitteln. Veranschaulicht wird zunächst der Begriff der Geodäte als einer lokal geraden Linie, 


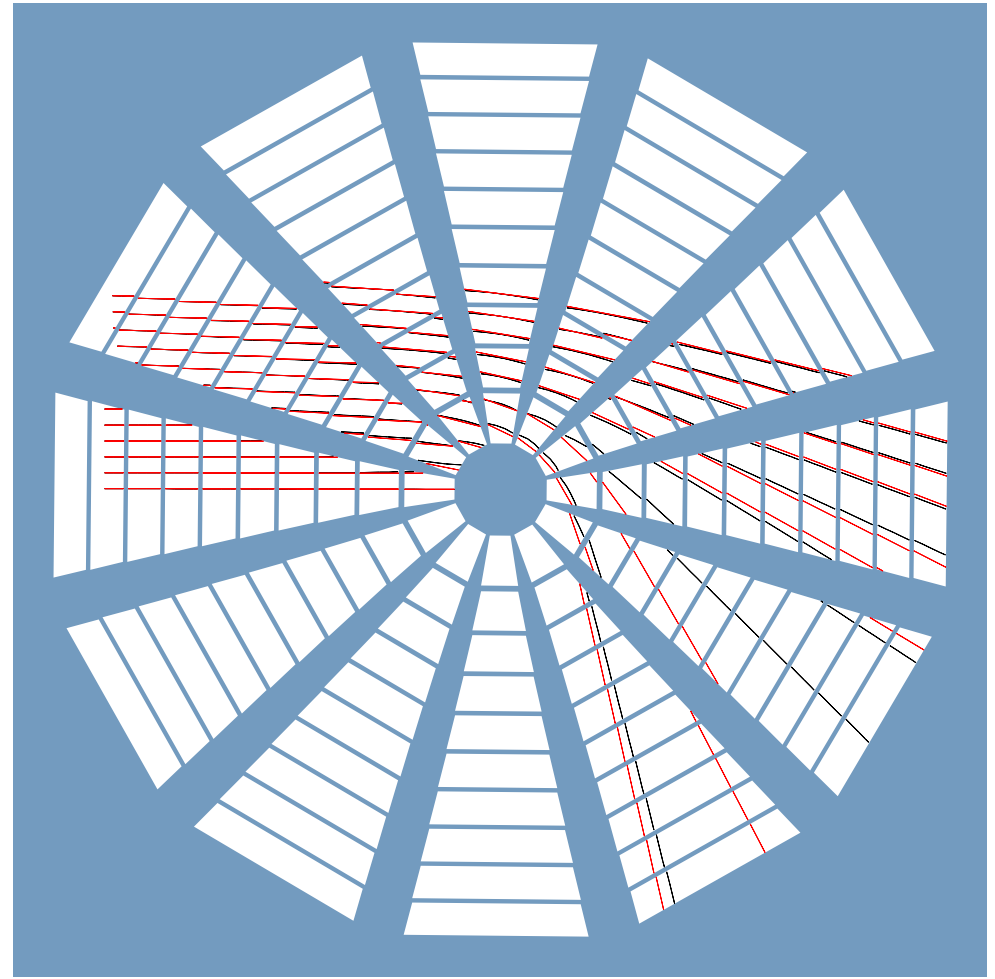

(a)

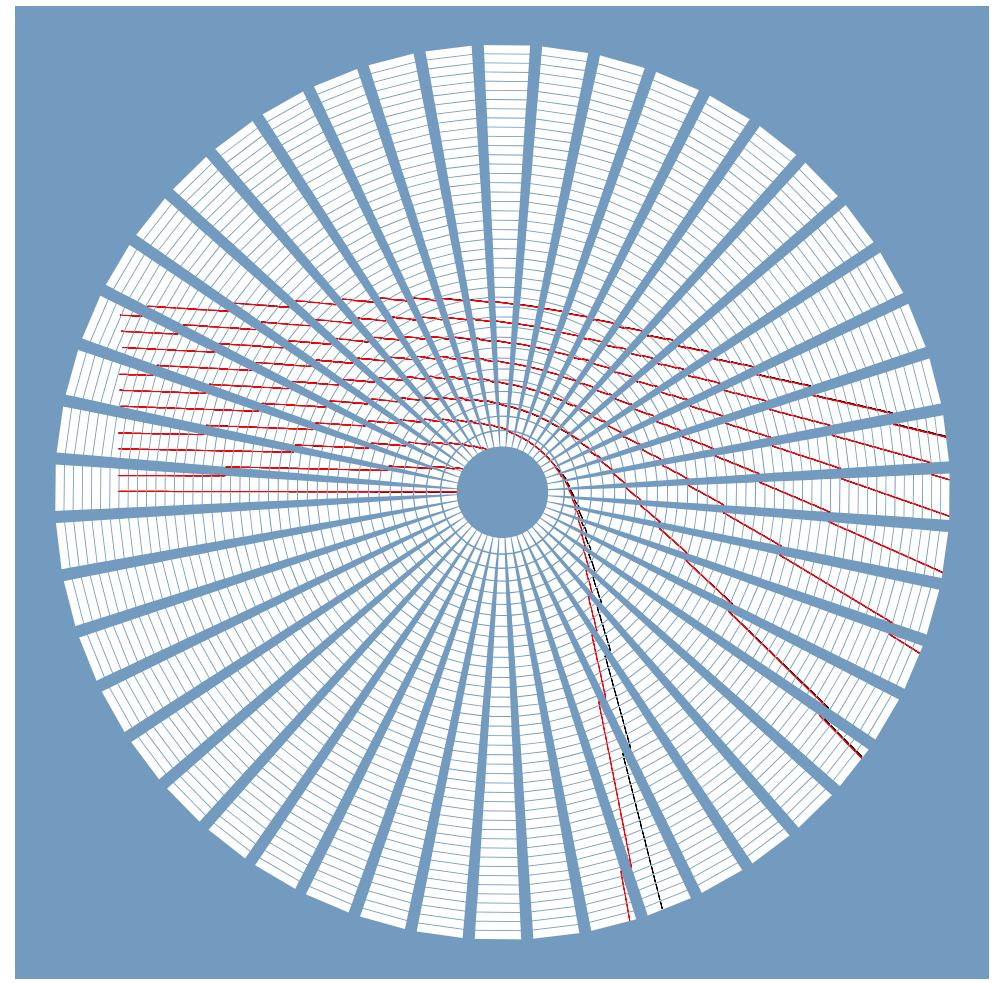

(b)

Abbildung 16. Auf Sektormodellen konstruierte Geodäten (rote Linien) im Vergleich mit numerischen Lösungen der Geodätengleichung (schwarze Linien). (a) Sektormodell mit der im Workshop verwendeten Auflösung. (b) Sektormodell mit der vierfachen Auflösung in jeder Koordinatenrichtung. 


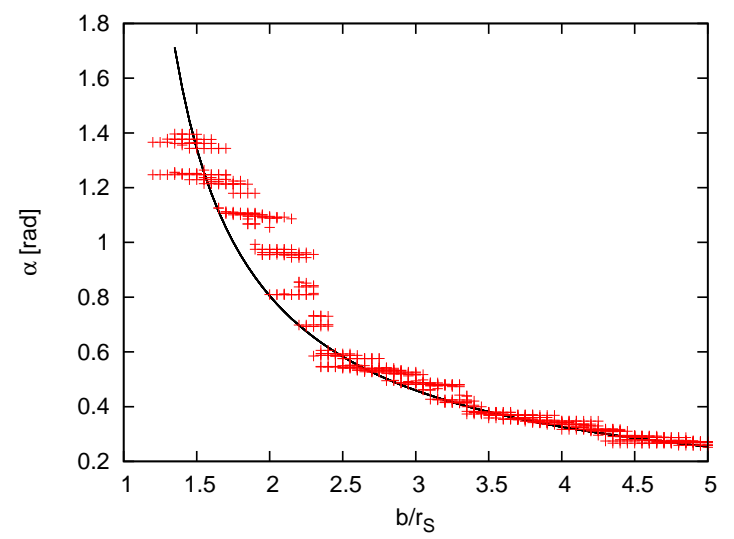

(a)

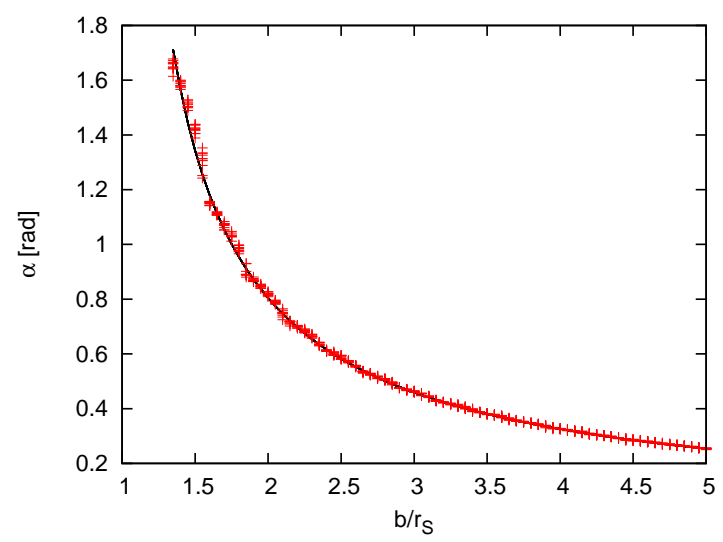

(b)

\begin{abstract}
Abbildung 17. Zusammenhang zwischen dem Ablenkwinkel $\alpha$ und dem Stoßparameter $b$ einer Geodäte, berechnet durch Konstruktion der Geodäten auf einem Sektormodell (Kreuze) sowie durch Integration der Geodätengleichung (Linie). (a) Sektormodell mit der im Workshop verwendeten Auflösung. (b) Sektormodell mit der vierfachen Auflösung in jeder Koordinatenrichtung.
\end{abstract}

indem diese Definition auf einem Sektormodell mit dem Lineal unmittelbar umgesetzt wird (Abschnitt 2.1). Weiter wird anschaulich klar, dass eine Geodäte nach dem Durchqueren eines Bereichs gekrümmten Raums eine andere Richtung hat als zuvor (Abschnitt 2.2), wodurch das Zustandekommen der Lichtablenkung im Schwerefeld verdeutlicht wird. Da die konstruierten Geodäten Lösungen der Geodätengleichung darstellen, erhält man quantitativ richtige Ergebnisse. Deren Genauigkeit ist wegen der relativ groben Auflösung der von Hand erstellten und eingesetzten Sektormodelle nicht hoch. Aus didaktischer Sicht ist eine grobe Auflösung jedoch vorteilhaft. Die Defizitwinkel sind dann so groß, dass die Auswirkungen der Krümmung an einzelnen Vertizes verdeutlicht werden können. So entsteht ein klares Bild von dem Zusammenhang zwischen der Krümmung und dem Verlauf benachbarter Geodäten (Abschnitt 2.5). In diesem Beitrag werden nur raumartige Geodäten betrachtet. Eine Erweiterung auf Geodäten in der Raumzeit wird in einem Folgebeitrag beschrieben (Kraus und Zahn 2018).

Der in diesem Beitrag vorgestellte Workshop zu Geodäten und Lichtablenkung entstand in einem Wechselspiel zwischen Erprobung und Weiterentwicklung (Kraus und Zahn 2005, Zahn und Kraus 2010, 2013, Kraus und Zahn 2016). Tests wurden vorwiegend mit Schulklassen der Oberstufe sowie mit Lehramtsstudierenden durchgeführt.

Für das vorgestellte Material gibt es, je nach Ziel und Zeitbudget, verschiedene Einsatzmöglichkeiten. Wenn das Ziel ein kurzer und direkter Zugang zur gravitativen Lichtablenkung ist, beispielsweise für einen Astronomiekurs, kann der vorgestellte Workshop wie in den Abschnitten 2.1 bis 2.3 beschrieben mit fertigen Vorlagen der Sektormodelle durchgeführt werden. Vorkenntnisse zum Begriff der Metrik sind 
dann nicht erforderlich; die zeichnerische Konstruktion ist einfach durchzuführen und vermittelt ein fachlich befriedigendes Konzept von Lichtbahnen als Geodäten. Ist eine Einführung in die Grundkonzepte der Allgemeinen Relativitätstheorie das Ziel, dann kann man die Sektormodelle der Kugeloberfläche und der Äquatorebene des Schwarzen Lochs von den Teilnehmer/innen selbst berechnen lassen. Der Kurs vermittelt dann die Fähigkeit, anhand einer vorgegebenen Metrik die Geometrie einer Fläche zu untersuchen. Dabei werden Aufgaben zeichnerisch gelöst, die in einem Standardkurs rechnerisch bearbeitet würden. Da Sektormodelle und die zeichnerische Konstruktion von Geodäten auf direkte Weise der mathematischen Beschreibung durch die Metrik und die Geodätengleichung entsprechen, kann dieses Material auch als Ergänzung zu einer üblichen, mathematisch ausgerichteten Vorlesung eingesetzt werden, um die geometrische Anschauung zu stärken.

\subsection{Vergleich mit anderen anschaulichen Zugängen}

Im Vergleich mit anderen bildlichen Darstellungen von Geodäten zeichnen sich Konstruktionen auf Sektormodellen dadurch aus, dass sie den lokal geraden Verlauf deutlich zum Ausdruck bringen und dass sie einfach zu erstellen sind.

Zur Erklärung der durch Lichtablenkung bewirkten optischen Phänomene, z. B. der Doppelbilder, werden üblicherweise Grafiken eingesetzt, die Lichtwege als gebogene Linien darstellen. In diesem Zusammenhang werden Lichtwege auch häufig als „krumm“ bezeichnet. Dass Lichtwege Geodäten, also (lokal) gerade Linien sind, kommt in diesen Grafiken und auch in der sprachlichen Beschreibung nicht zum Ausdruck, was zu Fehlvorstellungen führen kann. Die Konstruktion auf den Sektormodellen verdeutlicht, dass der lokal gerade Verlauf der Geodäte und das Auftreten von Lichtablenkung nicht im Widerspruch stehen (Abb. 8). Es kann auch der Bezug zu den gekrümmt dargestellten Lichtwegen hergestellt werden: Auf einer Weltkarte ist die Erdoberfläche auf eine Ebene projiziert und Geodäten der Erdkugel erscheinen als gekrümmte Linien. Dies sind Verzerrungen, die der Projektion geschuldet sind. Analog werden in einer Projektion, die das Sektormodell aus Abb. 8 auf einen ebenen Kreisring abbildet, Verzerrungen auftreten, welche die Geodäten der Äquatorebene des Schwarzen Lochs als gekrümmte Linien erscheinen lassen.

Eine häufig verwendete bildliche Darstellung zeigt Geodäten auf der Einbettungsfläche der Äquatorebene eines Sterns oder eines Schwarzen Lochs mit dem Ziel, die Lichtablenkung zu veranschaulichen (d'Inverno 1992, S. 209). Dies ist äquivalent zu den in Abschnitt 2.2 konstruierten Geodäten. Wenn man beim dortigen Sektormodell die Sektoren an den gemeinsamen Kanten zusammenfügt, erhält man eine Facettenfläche, welche näherungsweise die Einbettungsfläche darstellt. Für die Geodäten auf der Einbettungsfläche gilt derselbe Vorbehalt wie für die Geodäten auf dem Sektormodell: Der dargestellte Unterraum ist rein räumlich, so dass die gravitative Lichtablenkung in Form einer Analogie mit raumartigen Geodäten illustriert wird. Unsere Erfahrung zeigt, dass das Konzept der Einbettungsfläche für die Zielgruppe dieser Workshops schwierig ist. 
Man muss damit rechnen, dass die Darstellung als geometrische Form des Schwarzen Lochs fehlinterpretiert wird (Zahn und Kraus 2010). Im Vergleich zu Einbettungsflächen haben Sektormodelle den Vorteil, dass ihre Berechnung einfacher ist, insbesondere wenn das in Abschnitt 2.4 beschriebene vereinfachte Verfahren angewandt wird. Sie lassen sich außerdem auf einfache Weise als Anschauungsmodelle aus Papier erstellen und gut vervielfältigen, so dass alle Teilnehmer/innen eines Workshops die Konstruktion von Geodäten auf eigenen Vorlagen selbst durchführen können.

Eine Beschreibung von Geodäten, die mit der Darstellung auf Sektormodellen verwandt ist, ist die von diSessa (1981) entwickelte Konstruktion auf sogenannten Keilkarten (wedge maps). Eine Keilkarte entsteht, wenn die Symmetrieebene einer sphärisch-symmetrischen Raumzeit durch radiale Schnitte in Streifen zerlegt wird; diese Streifen werden als ungekrümmt angesehen. Auf den Streifen werden Geodäten nach dem Prinzip des Regge-Kalküls auf numerische Weise bestimmt. Die Konstruktion der Geodäten auf der Keilkarte folgt also demselben Prinzip wie hier für die Sektormodelle beschrieben. Das numerische Vorgehen ist anspruchsvoller als die hier eingesetzte zeichnerische Lösung, sowohl was die mathematische Beschreibung angeht als auch wegen der erforderlichen Programmierkenntnisse.

\subsection{Ausblick}

In Teil I wurden drei Grundfragen aufgeworfen, die bei einer Einführung in die Allgemeine Relativitätstheorie beantwortet werden sollten: Was ist eine gekrümmte Raumzeit? Wie bewegt sich Materie in einer gekrümmten Raumzeit? Welcher Zusammenhang besteht zwischen der Materieverteilung und der Krümmung der Raumzeit? Der Begriff des gekrümmten Raums bzw. der gekrümmten Raumzeit wurde in Teil I verdeutlicht. Zur Beantwortung der zweiten Frage beschreibt der vorliegende Teil II Geodäten im Raum und der Folgebeitrag Geodäten in der Raumzeit (Kraus und Zahn 2018). Ein vierter Teil dieser Serie wird auf den Zusammenhang zwischen der Krümmung der Raumzeit und der Materieverteilung eingehen.

\section{Literatur}

Brewin L 1993 Particle paths in a Schwarzschild spacetime via the Regge calculus Class. Quantum Grav. 10 1803-23

d'Inverno R 1992 Introducing Einstein's Relativity (Oxford: Clarendon Press) diSessa A 1981 An elementary formalism for general relativity Am. J. Phys. 49 (5) $401-11$

Hartle J 2003 Gravity (San Francisco: Addison Wesley)

Hormann K 2005 Barycentric Coordinates for Arbitrary Polygons in the Plane, Technical Report No. 5, Institute of Computer Science, Clausthal University of Technology, Germany 
Kraus U und Zahn C 2005 Wir basteln ein Schwarzes Loch - Unterrichtsmaterialien zur Allgemeinen Relativitätstheorie Praxis der Naturwissenschaften Physik, Didaktik der Relativitätstheorien 4/54 38-43

Kraus U und Zahn C 2016 Lichtablenkung für die Schule: Von der Metrik zur Geodäte Astronomie und Raumfahrt im Unterricht 53 (3-4/2016) 43-9

Online, mit Begleitmaterial: www.tempolimit-lichtgeschwindigkeit.de/aur16

Kraus U und Zahn C 2018 Sektormodelle - Ein Werkzeugkasten zur Vermittlung der Allgemeinen Relativitätstheorie. III: Geodäten in der Raumzeit, eingereicht

Natário J 2011 General Relativity Without Calculus (Springer)

Regge T 1961 General relativity without coordinates Il Nuovo Cimento 19 558-71

Weinberg S 1972 Gravitation and Cosmology (Wiley)

Williams R M und Ellis G F R 1981 Regge Calculus and Observations. I. Formalism and Applications to Radial Motion and Circular Orbits Gen. Rel. Grav. 13 (4) 361-95

Williams R M und Ellis G F R 1984 Regge Calculus and Observations. II. Further Applications Gen. Rel. Grav. 16 (11) 1003-21

Zahn C und Kraus U 2010 Workshops zur Allgemeinen Relativitätstheorie im Schülerlabor „Raumzeitwerkstatt“ an der Universität Hildesheim PhyDid B DD 09.03

Zahn C und Kraus U 2013 Bewegung im Gravitationsfeld in der Allgemeinen Relativitätstheorie - ein neuer Zugang auf Schulniveau PhyDid B DD 17.13

Zahn C und Kraus U 2014 Sektormodelle - Ein Werkzeugkasten zur Vermittlung der Allgemeinen Relativitätstheorie. I: Gekrümmte Räume und Raumzeiten www.tempolimit-lichtgeschwindigkeit.de/sectormodels1

Deutsche Übersetzung von: Sector models-A toolkit for teaching general relativity: I. Curved spaces and spacetimes Eur. J. Phys. 35 (5) 055020 (Teil I)

Zahn C und Kraus U 2018 Online-Ressourcen zum Beitrag, WWw.tempolimit-lichtgeschwindigkeit.de/sectormodels2 